\title{
Geoarcheological Investigations of Wetland Cell D Within the Dallas Floodway Extension Project Area, Dallas, Texas
}

David Shanabrook

Geo-Marine, Inc.

Duane E. Peter

Steven M. Hunt

Geo-Marine, Inc.

Follow this and additional works at: https://scholarworks.sfasu.edu/ita

Part of the American Material Culture Commons, Archaeological Anthropology Commons, Environmental Studies Commons, Other American Studies Commons, Other Arts and Humanities Commons, Other History of Art, Architecture, and Archaeology Commons, and the United States History Commons

Tell us how this article helped you.

This Article is brought to you for free and open access by the Center for Regional Heritage Research at SFA ScholarWorks. It has been accepted for inclusion in Index of Texas Archaeology: Open Access Gray Literature from the Lone Star State by an authorized editor of SFA ScholarWorks. For more information, please contact cdsscholarworks@sfasu.edu. 
Geoarcheological Investigations of Wetland Cell D Within the Dallas Floodway Extension Project Area, Dallas, Texas

\section{Creative Commons License}

\section{(c) (i) $\Theta($}

This work is licensed under a Creative Commons Attribution-NonCommercial-No Derivative Works 4.0 International License. 


\title{
GEOARCHEOLOGICAL INVESTIGATIONS OF WETLAND CELL D WITHIN THE DALLAS FLOODWAY EXTENSION PROJECT AREA, DALLAS, TEXAS
}

\author{
by \\ David Shanabrook \\ Duane E. Peter \\ Steven M. Hunt \\ Principal Investigator \\ Duane E. Peter
for
U.S. Army Corps of Engineers
Fort Worth District
P. O. Box 17300 \\ Fort Worth, Texas 76102-0300
}

MISCELLANEOUS REPORTS OF INVESTIGATIONS

NUMBER 233

Geo-Marine, Inc.

550 East 15th Street

Plano, Texas 75074

February 2002 


\section{CONTRACT DATA}

The preparation of this document was accomplished under Contract No. DACA63-99-D-0010, Delivery Order No. 0033 (GMI project number 1010-A33/10100.00.33), with the U.S. Army Corps of Engineers, Fort Worth District, P.O. Box 17300, Fort Worth, Texas 76102-0300. 


\section{MANAGEMENT SUMMARY}

The Dallas Floodway Extension project is designed to provide flood damage reduction and environmental restoration within the Trinity River flood plain between the Corinth Street Viaduct and Loop 12. The U.S. Army Corps of Engineers, Fort Worth District, contracted with Geo-Marine, Inc., to conduct an archeological assessment of the proposed Wetland Cell D. The archeological assessment was to identify any potential archeological sites that may be eligible for inclusion in the National Register of Historic Places and to provide an assessment of the potential for buried landforms in the project area that may have intact archeological resources present. The geoarcheological investigations, involving the excavation of 10 backhoe trenches and the review of previous data collected within the Upper Trinity River drainage, revealed that the flood plain sediments of the Trinity River are quite variable, both horizontally and vertically. The data collected during the current investigations suggest that Cell D is located along or near the axis of a recent Trinity River meander belt that has cut deeply into the preexisting Quaternary sediments. This channel cut was then rapidly filled with fine-grained deposits possibly derived from the surrounding uplands and other areas upstream. In addition, the trenching revealed that the upper portions of the sediments within Cell D have been disturbed during the recent historic period, presumably by the construction of the Interstate 45 bridge and the activities of the nearby Dallas Central Wastewater Treatment Plant.

The geoarcheological investigation in Wetland Cell D showed little potential for buried cultural deposits. The only cultural materials encountered were historic artifacts in the recent fill in the upper zone of the trenches. Considering the density of the material in some trenches, this is likely the result of dumping. The proposed development of Cell D will, therefore, not affect historic properties. Although the variability of the sediments in Cell D may be mirrored elsewhere in the proposed Dallas Floodway Extension project, it is impossible to extrapolate the results of this investigation to the remaining proposed wetlands. Given the variability exhibited by Cell D and the surrounding area, it is recommended that each proposed wetland will require similar geoarcheological investigations prior to any construction activities within the area. 


\section{TABLE OF CONTENTS}

MANAGEMENT SUMMARY ..........................................................................................ii

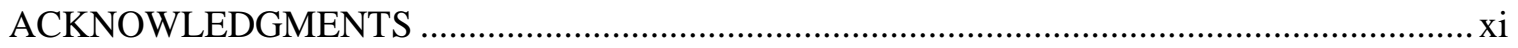

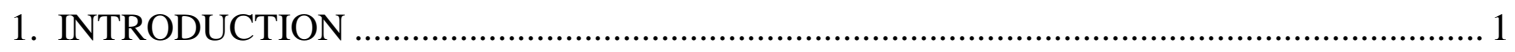

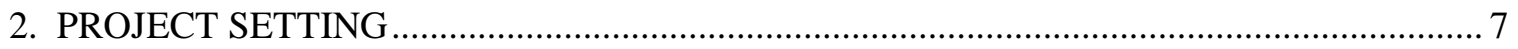

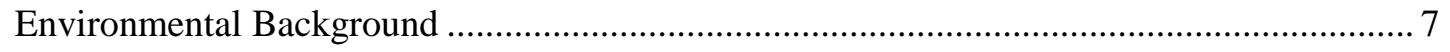

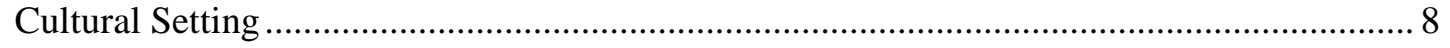

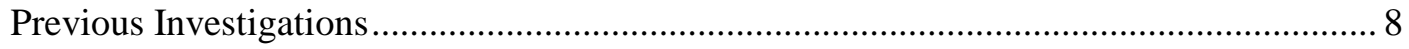

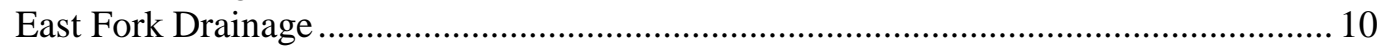

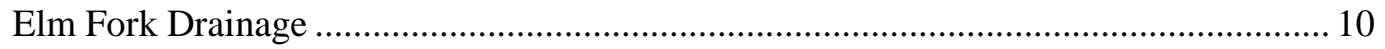

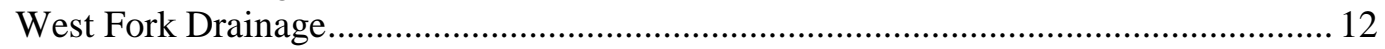

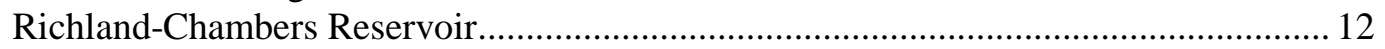

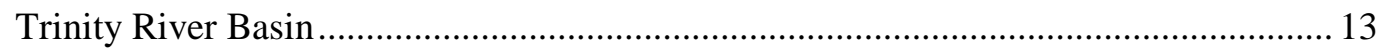

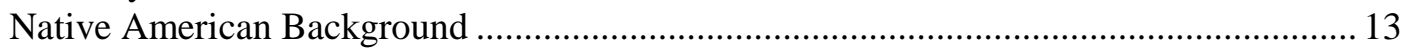

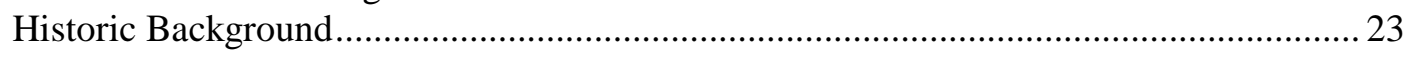

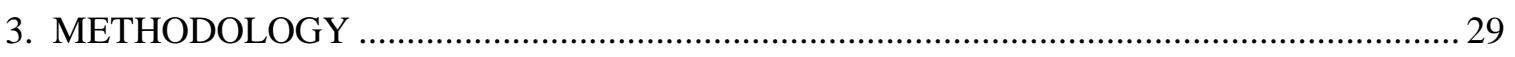

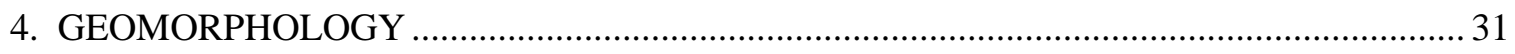

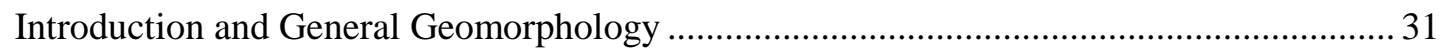

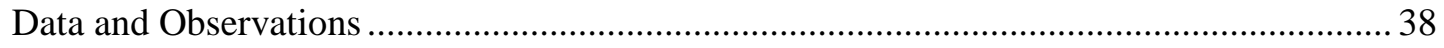

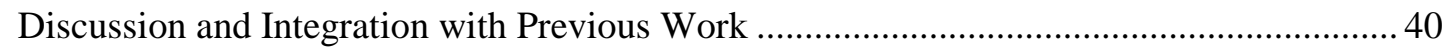

Summary and Archeological Implications......................................................................... 48

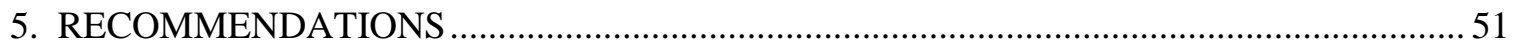

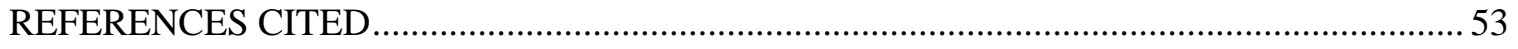

APPENDICES

A: BACKHOE TRENCH PROFILE DESCRIPTIONS ….............................................. A-1

B: SELECTED PREVIOUSLY RECORDED GEOPROBE ${ }^{\circledR}$ EC PROFILES WITH INTERPRETED ALLUVIAL UNITS RELEVANT TO WETLAND CELL D............ B-1 


\section{LIST OF FIGURES}

1. General location of Wetland Cell D within Dallas County ..................................................... 2

2. Map of Wetland Cell D project showing the backhoe trenches dug during the current investigation, as well as previously recorded sites and previous geoarcheological investigations

3. Historic maps from the 1850s to the latter 1950s show a stable active meander belt in the Trinity River flood plain area ............................................................................................. 9

4. The upper Trinity River basin showing archeological sites mentioned in the text .................. 11

5. Geomorphological map of a portion of the Dallas Floodway and proposed extension............. 34

6. Conceptual geological cross section of the Trinity River valley in the Dallas Floodway

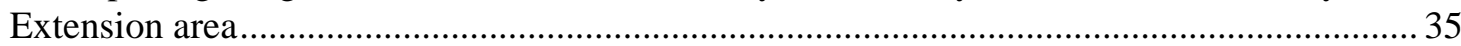

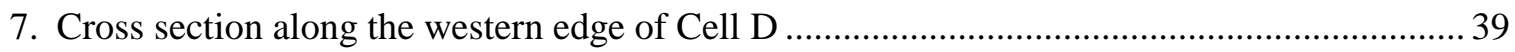

8. Cross section showing relationship of Cell D deposits to those at site 41DL337 to the northwest and sites 41DL318 and 41DL319/357 to the southeast .......................................... 41

9. Relationship of the Wetland Cell D project to previous investigations of the geomorphology of the Dallas Floodway Extension project area. 


\section{LIST OF TABLES}

1. Native American Chronology for the Upper Trinity River Basin ........................................... 14

2. Lithologic Properties, Depositional Environments, and Inferred Ages of Alluvial Stratigraphic Units in the Upper Trinity River

3. Comparison of Upper Trinity River Stratigraphy to Units in the Dallas Floodway Extension Area. 


\section{ACKNOWLEDGMENTS}

This project required the efforts of many people to reach completion. Mr. David Shanabrook served as the geologist for the project, without whom the fieldwork and analysis could not have proceeded. The heavy equipment operator was Mr. James Thomas, whose services were also invaluable. Mr. Steven Hunt assisted Mr. Shanabrook during the fieldwork and assembled the final report. Mr. Duane Peter served as Principal Investigator for the project, assuring that the project was completed in a timely and professional manner. Ms. Donna Davis, Ms. Elizabeth Burson, and Mr. Ronnie Roller prepared the figures for the report. Ms. Sharlene Allday served as editor for the report. Finally, Ms. Denise Pemberton prepared the report for publication. 


\section{CHAPTER 1 INTRODUCTION}

This report describes the cultural resources investigations conducted within Wetland Cell D of the Dallas Floodway Extension project. The Dallas Floodway Extension project is designed to provide flood damage reduction and environmental restoration within the Trinity River flood plain between the Corinth Street Viaduct and Loop 12. The U.S. Army Corps of Engineers, Fort Worth District, contracted with Geo-Marine, Inc., under Contract No. DACA63-99-D-0010, Delivery Order No. 0033, to conduct an archeological assessment of the proposed area for Wetland Cell D. This work is being conducted in compliance with Section 106 of the National Historic Preservation Act of 1966 as amended through 1992 (P.L. 89-665 et seq.). The archeological assessment was to identify any potential archeological sites that may be eligible for inclusion in the National Register of Historic Places and to provide an assessment of the project area for the potential for buried landforms that may have intact archeological resources present. Fieldwork was conducted on June 19 and 20, 2001, by David Shanabrook, Geoarcheologist, and Steven Hunt, Field Supervisor. Mr. Duane Peter served as Principal Investigator.

Wetland Cell D is located near the Interstate 45 (I-45) bridge as it crosses the Trinity River (Figures 1 and 2) and is approximately 2,500 feet (762 m) in length and 300 feet $(92 \mathrm{~m})$ in width. The approximate total acreage is 20 acres (8 hectares). Depths of the project excavation varied from the edges of the wetland cell where the existing grade was used to a depth of 10 feet $(3 \mathrm{~m})$ at the center of the excavated swale. Over 60 percent of the proposed excavated swale was less than 6 feet $(2 \mathrm{~m})$ in depth. Ten backhoe trenches were excavated to examine the sediments within Wetland Cell D and, in conjunction with the results from excavated trenches from previous investigations in the vicinity, were the basis for assessing the potential for buried landforms within the project area. Although dense forest vegetation limited the number of trenches that could be excavated, the 10 trenches adequately characterize the depositional environment of the area and its potential for containing buried occupational surfaces.

The following report is divided into five chapters. Chapter 2 provides an environmental background for the Dallas Floodway project and a summary of the cultural history for the Dallas area. Chapter 3 describes the methods used during the geoarcheological investigation of Wetland Cell D, and Chapter 4 summarizes the results of the investigation. Finally, Chapter 5 provides recommendations based on the results of the current investigation. Following Chapter 5 is a list 
Geoarcheological Investigations of Wetland Cell D within the Dallas Floodway Extension Project Area, Dallas, Texas

\section{Figure}

1. General location of Wetland Cell D within Dallas County 
Figure

2. Map of Wetland Cell D project showing the backhoe trenches dug during the current investigation, as well as previously recorded sites and previous geoarcheological investigations 
Geoarcheological Investigations of Wetland Cell D within the Dallas Floodway Extension Project Area, Dallas, Texas

\section{figure 2}


of the references cited in the main body of the report. Profile descriptions for the 10 backhoe trenches are provided in Appendix A. Selected Geoprobe ${ }^{\circledR}$ electrical conductivity (EC) profiles from the 1997 geoarcheological investigations (Cliff et al. 1998) relevant to Wetland Cell D are presented in Appendix B. In some instances, the interpretations of the alluvial units represented by the EC profiles have been altered from the original to reflect more detailed knowledge of the formation processes in this area. 
Geoarcheological Investigations of Wetland Cell D within the Dallas Floodway Extension Project Area, Dallas, Texas 


\section{CHAPTER 2 PROJECT SETTING}

\section{ENVIRONMENTAL BACKGROUND}

Dallas County is part of the Texan biotic province defined by Blair (1950) as an intermediate zone between the forests of the Austroriparian and Carolinian provinces and the grasslands of the Kansan, Balconian, and Tamaulipan provinces. Some species reach the limits of their range in the Texan province. Almost all of Dallas County falls within the Blackland Prairie, one of several tall grass prairies present in this part of Texas. The vegetation in the Blackland Prairie is dominated by grasses in the uplands; woodlands are restricted to stream courses and river bottoms. Prior to the disturbances associated with the modern floodway, the Trinity River bottoms would have been covered with a water oak-elm-hackberry forest, with occasional grassy clearings and shallow-water marshes and ponds (McMahan et al. 1984). In areas along the Trinity River where this bottomland forest is preserved today, it can include cedar elm, American elm, willow oak, southern red oak, white oak, black willow, cottonwood, red ash, sycamore, pecan, bois d'arc, flowering dogwood, dewberry, coral-berry, dallisgrass, switchgrass, rescuegrass, bermudagrass, eastern gamagrass, Virginia wildrye, Johnsongrass, giant ragweed, yankeeweed, and Leavenworth eryngo (McMahan et al. 1984:22). Most of these species were probably present prehistorically. Also possibly present aboriginally were cherry, sweetgum, hawthorn, hickory, blackberry, sedge, Indiangrass, giant cane, and beaked panicum (United States Department of Agriculture [USDA] 1980:50, 92). The faunal community in this region has undergone extensive changes due to the expansion of the Dallas-Fort Worth metroplex. Animal species that would have previously inhabited the area include bobwhite, quail, pheasant, meadowlark, field sparrow, sage grouse, lark bunting, various species of turtles, cottontail, swamp rabbit, squirrel, muskrat, raccoon, gray fox, red wolf, and white-tailed deer (Schmidly 1983; USDA 1980:50).

This region has a warm temperate, subtropical, and humid climate that is generally mild; periods of extremely hot and cold weather are usually limited in duration. Yearly rainfall is fairly evenly distributed, but the maximum rainfall occurs in April and May and the minimum in August. Much of this rainfall occurs in the form of heavy thunderstorms, with rapid runoff that allows only limited absorption of water by the soil. Snowfall is rare, averaging less than $2.5 \mathrm{~cm}$ (1 in) per year. The snowfall is generally present for less than one week. The prevailing winds are

southerly. Temperatures remain above 0EC (32EF) approximately 240 days each year (USDA 1964:72-73, 1969:51-52). 
Dallas County is underlain by four geological formations: the Eagle Ford Shale, the Austin Chalk, the Taylor Marl, and the Neylandville Marl (Allen and Flanigan 1986). In addition, Pleistocene terrace deposits and Holocene alluvium are found along major streams and their tributaries (Cliff et al. 1998; Ferring 1990). The proposed Dallas Floodway Extension is confined entirely to the existing flood plain of the Trinity River and two of its major branches: the Elm Fork and the West Fork. Prior to the completion of the Dallas Floodway in 1932, the Elm Fork of the Trinity River had flowed east and north of the current floodway, to join the former channel of the West Fork about where Hampton Road meets Irving Boulevard. From there, the Trinity River flowed south and east, between downtown Dallas and the present floodway, and resumed its present channel east of the Corinth Street Bridge. The West Fork originally flowed south of the current floodway, crossing it west of the Hampton Road Bridge, before joining with the Elm Fork. Thus, prior to the construction of the Dallas Floodway, the confluence of the Elm Fork and the West Fork was approximately $4.2 \mathrm{~km}$ east of their current confluence (Figure 3).

The Soil Conservation Service (SCS) has mapped two soils within the Cell D project area: Trinity clay, frequently flooded, and Pits and Dumps. The Pits and Dumps map unit consists of areas where limestone or shale have been removed, resulting in areas 2.4 to $22.9 \mathrm{~m} \mathrm{(8-75} \mathrm{ft}$ ) below the original ground surface. Mounds of rubble or shale may be present within the remaining shallow pits, and standing water may be present in the lowest parts (USDA 1980:31).

Trinity clay, frequently flooded, is a deep and nearly level soil found in flood plains that usually flood two or three times each year; the flood waters vary from shallow to moderately deep. Trinity series soils are classified as very fine, montmorillonitic, thermic Typic Pelluderts (USDA 1980:Table 21). Small areas of Ovan, Seagoville, and Trinity clay, occasionally flooded, may be included within this map unit, making up no more than 20 percent of the area. A typical soil profile for Trinity clay, frequently flooded, begins with about $18 \mathrm{~cm}$ (7 in) of a dark gray (10YR 4/1) clay A11 horizon. This is underlain by a dark grayish brown (2.5Y 4/2) clay A12 horizon from 18 to $51 \mathrm{~cm}$ (7-20 in). Beneath this is a very dark gray (10YR 3/1) clay A13 horizon from 51 to $114 \mathrm{~cm}$ (20-45 in), and a dark grayish brown (2.5Y 4/2) clay A14 horizon from 114 to $173 \mathrm{~cm}$ (45-68 in) below surface (USDA 1980:36, 67-68).

\section{CULTURAL SETTING}

\section{Previous Investigations}

The history of archeological investigations within the upper Trinity River drainage and the current culture-historical framework for the area are aptly summarized in three major reports concerning the archeology of the upper Trinity River basin (Peter and McGregor 1988; Prikryl 1990; Yates and Ferring 1986). Although the combined efforts of professional and avocational archeologists have resulted in the recording of numerous sites, it is apparent that a great deal of research remains to be done. More than a decade ago, McGregor (1988:27-29) noted that much of the excavation effort within the upper Trinity River basin has been focused on reservoir development, and the situation has not changed materially since then, although extensive work in the area has also been conducted by avocationalists. 
Figure

3. Historic maps from the 1850s to the latter 1950s show a stable active meander belt in the Trinity River flood plain area

(sources.....) 


\section{East Fork Drainage}

Reservoir studies along the East Fork have included work at Lake Ray Hubbard and Lake Lavon, east and northeast of Dallas, respectively (Figure 4). Lake Lavon was surveyed in 1949, and test excavations were conducted at the Campbell Hole (41COL10) and Hogge Bridge (41COL1) sites (Stephenson 1949a, 1949b). Additional excavations conducted at the Hogge Bridge site resulted in the formal definition of the Wylie focus-a Late Prehistoric manifestation believed to be characterized by arrow points, flexed burials, large pits, and trade pottery from cultures to both the east and west (Stephenson 1952a, 1952b). In the 1970s, excavations were carried out by Southern Methodist University (SMU) as a result of the planned enlargement of Lake Lavon (Dawson and Sullivan 1973; Lynott 1975). Lake Ray Hubbard was surveyed with the help of members of the Dallas Archeological Society (DAS) in 1963 (Harris and Suhm 1963). Subsequently, excavations were carried out at the Glen Hill (41RW4) and Upper Rockwall (41RW2) sites (Ross 1966) and the Lower Rockwall site (41RW1; Lorrain and Hoffrichter 1968). Much of this work was concentrated on excavations at sites with Wylie focus pits in an effort to better understand the function of these large features. A low level of professional work - most of which is carried out to meet compliance with the requirements of the National Historic Preservation Act — continues to be conducted within the East Fork basin (Austin 1993a; Cliff et al. 1989, 1996; Hunt 1993; Hunt and Cliff 1998; Hunt and Peter 1996a, 1996b, 1998a; Hunt, Peter, and Allday 1991; Hunt et al. 1992; Peter et al. 1990; Skinner 1990a, 1990b, 1993).

\section{Elm Fork Drainage}

Research on the Elm Fork of the Trinity River, northwest of Dallas, has largely centered on Lewisville Lake and Lake Ray Roberts, farther north. As with Lake Lavon, R. L. Stephenson (1949a, 1950) surveyed the area of Lewisville Lake (then known as Garza-Little Elm Reservoir) in 1948. At least three sites (41DN5, 41DN6, and 41DN12) were tested by Stephenson, but the results were never published (Prikryl 1990). Subsequently, as the dam was being constructed, local avocational archeologists found and excavated the Lewisville site (41DN72), an apparent Paleo-Indian occupation site that yielded a Clovis point in association with extinct fauna and apparent hearths with radiocarbon dates of greater than 37,000 years ago (Crook and Harris 1957, 1958, 1961). Further work conducted at the site in 1979 and 1980, while unpublished, indicates that the site is indeed of Clovis-age but that the early dates were derived from lignite coal (Prikryl 1990). More recent work at Lewisville Lake has included a shoreline survey conducted by the Richland Archeological Society (Nunley 1973) and a survey of the lake peripheries by the University of North Texas (UNT; Lebo and Brown 1990), test excavations of 23 prehistoric and 16 historic sites by UNT (Brown and Lebo 1991), and data recovery excavations at three historic and five prehistoric sites (Ferring and Yates 1998; Lebo 1995a). Farther north along the Elm Fork, research at Lake Ray Roberts began in 1972 with a reconnaissance survey (Bousman and Verrett 1973), followed by several intensive surveys of the lake area (Skinner 1982a), site testing (Prikryl and Yates 1987; Skinner 1982b), and data recovery excavations at 26 historic and 12 prehistoric sites (Ferring and Yates 1997; Lebo 1995b; Skinner and Baird 1985). Ferring's (1989, 2001) investigations just below the Lake Ray Roberts dam that were associated with the Paleo-Indian-aged Aubrey site, 41DN479, examined deeply stratified deposits below the top of the Elm Fork flood plain. Recent work within the 
Figure

4. The upper Trinity River basin showing archeological sites mentioned in the text 
Elm Fork valley unconnected with either of these two reservoirs includes field school excavations by the University of Texas at Arlington at the Northlake site, 41DL234, on Grapevine Creek, in the mid-1970s (Morgan 1975); a summary of Elm Fork prehistory based on excavated data and surface collections (Prikryl 1990); data recovery excavations at site 41DL270, along Denton Creek (Anthony and Brown 1994); and several smaller survey and evaluation projects (Burson 2000a; Hunt and Peter 1997a; Hunt, Shanabrook, and Peter 1991; Hunt, White, and Gaither 1996; Hunt et al. 1995; Skinner and Kent 1998).

\section{West Fork Drainage}

Research along the West Fork of the Trinity River began later, but investigations at Joe Pool Lake provided the initial assemblage data necessary for a basic understanding of prehistoric adaptations in western Dallas and Tarrant counties. Located on Mountain Creek in southwest Dallas County, Joe Pool Lake was originally known as Lakeview Reservoir. Fieldwork began in 1977 with a survey that recorded 42 sites, including Archaic, Late Prehistoric, and Historic sites, within the project area (Skinner and Connors 1979). Test excavations were then undertaken at 15 prehistoric and eight historic sites (Ferring and Reese 1980; Raab, Bruseth, and McIntyre 1980; Raab et al. 1982). Finally, data recovery excavations were conducted from 1984 to 1986 at six prehistoric and 13 historic sites (Jurney, Lebo, and Green 1988; Peter and McGregor 1988). More recent excavations along the West Fork include limited excavations conducted at the River Bend site, 41TR68 (Peter et al. 1987); at sites 41TR119 (Edwards and Peter 1991) and 41TR138 in Fort Worth (Largent et al. 1994; Peter et al. 1998); and at the Fountain site (41TR136) in Arlington (Hanson and Kvernes 1997). In addition to this work, numerous small cultural resources surveys and site evaluations have been conducted within the West Fork basin (Austin 1993b; Brown 1988; Burson 2000b; Burson and Cliff 1999; Burson et al. 2000a, 2000b; Edwards 1991; Hunt 1991, 1997; Hunt and Krapf 1996; Hunt and Peter 1993a, 1993b, 1995 1996c, 1997b, 1997c, 1998b; Hunt and Peter, with Wright 1996; Hunt, Peter, and Morrell 1996; Hunt et al. 1993, 1994; Krapf and Hunt 1996; Peter and Cliff 1988; Peter and Gaither 1990; Peter, Hunt, and Green 1994).

\section{Richland-Chambers Reservoir}

Another major reservoir study was undertaken south of Dallas at Richland-Chambers Reservoir. The area of Richland-Chambers Reservoir was originally included in the proposed Tennessee Colony Reservoir, to be constructed on the Trinity River below Dallas (Chamberlin 1972; Richner 1982; Richner and Bagot 1978; Richner and Lee 1976, 1977), but this development was later canceled. Subsequently, dams were planned on both Richland and Tehuacana creeks, and a preliminary overview of the cultural resources was prepared (Burton and Connors 1979). Finally, the project was reduced to the Richland Creek impoundment and became known as the Richland-Chambers Reservoir. Fieldwork for the project was undertaken by SMU, beginning with a survey of the project area in 1980, during which 911 sites were discovered. This survey was followed by a testing phase, during which 270 sites were evaluated (Archaeology Research Program [ARP] 1982; Raab, Moir, and McGregor 1980, 1981). Data recovery excavations were undertaken at 15 prehistoric and 38 historic sites during four field seasons from June 1982 to December 1984 (Bruseth and Martin, eds. 1987; Bruseth and Moir 1987; Jurney and Moir, eds. 1987; McGregor and Bruseth 1987; Moir and Jurney, eds. 1987). 


\section{Trinity River Basin}

Recent large cultural resources management projects in Dallas County, within the basin of the main branch of the Trinity River, include the 1988 testing and mitigation excavations at site 41DL279 in the Dallas Central Business District adjacent to the historic flood plain of the Trinity River (Jurney and Andrews 1994), as well as the excavation of Freedman's Cemetery (Peter et al. 2000). Research projects for the Dallas Area Rapid Transit (DART) rail lines have included both archeological and architectural investigations (Adovasio 1992; ARP 1989, 1991; Dorward and Weston 1990; Dorward et al. 1990; Green and James 1996; Green et al. 1997; Jurney 1987a, 1987b, 1987c, 1987d; Jurney, with McElhaney 1987, 1988; Jurney, with McElhaney and Payton 1987; Jurney, with Moir, McElhaney, Payton, and McKnight 1988; Jurney, McElhaney, and Weston 1990; Jurney and Moir 1987; Jurney and Moir, with McElhaney 1987; Jurney and Moir, with McElhaney and Payton 1987; Jurney, Moir, Dorward, and Weston 1990, 1991; Jurney, Moir, and Peter 1987; Jurney, Peter, and McElhaney 1987, 1988; Jurney, Peter, McElhaney, Payton, and Girard 1987; Moir, Dorward, and Winchell 1991; Moir and Jurney 1987, 1988; Moir and Peter 1987; Moir et al. 1987a, 1987b; Myra L. Frank \& Associates 1987a, 1987b, 1987c, 1988a, 1988b, 1988c, 1988d, 1988e, 1990, 1993; Myra L. Frank \& Associates and ArchiTexas 1987, 1988; Myra L. Frank \& Associates and Burson \& Cox Architects, Inc., 1987a, 1987b, 1987c, 1987d; Skinner, Whorton, Trask, Scott, Caran, and Dillon 1996; Skinner et al. 1994; Weston and Dorward 1990; Winchell and Dorward 1991).

In addition to these large projects, Dallas County has been the focus of many smaller cultural resources surveys and evaluations within recent years; several projects have been in or near the flood plain of the main branch of the Trinity River (Bennett et al. 1981; McCormick 1976; Peter, Cliff, Freeman, McElhaney, and Allday 1991; Peter, Shepard, and Hunt 1994; Skinner and Whorton 1993, 1995; Skinner, Whorton, and Trask 1996; Skinner et al. 1990, 1991; Trask et al. 1997). In 1997, GMI conducted an archeological, architectural, and geoarcheological evaluation of the area of the proposed Dallas Floodway Extension, to run from the existing Dallas Floodway south to Interstate 20 (Cliff et al. 1998). Following this evaluation, the USACE sponsored test excavations at seven prehistoric sites near the intersection of I-45 and the Trinity River (Buysse 2000). The USACE has also sponsored geoarcheological investigations of the entire Dallas Floodway Extension (Cliff et al. 1999).

\section{Native American Background}

Despite a long history of archeological research in Northcentral Texas and the southern plains (Jelks 1967; Krieger 1946, 1947; Prewitt 1981, 1985), as well as several more recent summary overviews (Hofman et al. 1989; Prikryl 1990; Story et al. 1990; Vehik 1994), the chronological framework for the upper Trinity River basin is not well developed, and the available data allow the delineation of only a generalized chronology. Investigations at Joe Pool Lake (Peter and McGregor 1988) provided evidence for a refinement of the chronology for the Late Prehistoric period, although the overall regional applicability of the phases recognized there is still in some dispute. Prikryl (1990) presented a chronological sequence of six periods, but he relied almost entirely on diagnostic artifacts from surface contexts and comparisons to dated contexts distant from the upper Trinity River basin. Despite this, chronological data from recent excavations at Ray Roberts Lake and Lewisville Lake reportedly conform well to his suggested sequence (Ferring and Yates 1997, 1998). 
The chronology presented here (Table 1) is taken from the introduction to the regional preservation plan for the Prairie-Savanna Archeological Region, of which the upper Trinity River basin is a part (Prikryl 1993). A brief summary of the adaptations and archeological remains associated with these periods is presented below.

Table 1

Native American Chronology for the Upper Trinity River Basin (after Prikryl 1993)

\begin{tabular}{|c|c|c|c|}
\hline Years B.P. & \multicolumn{2}{|c|}{ Temporal Periods and Subdivisions } & Years B.C./A.D. \\
\hline 100 & Historic Indian & & A.D. 1850 \\
\hline 250 & \multirow{2}{*}{ Late Prehistoric } & II & A.D. 1700 \\
\hline 750 & & I & A.D. 1200 \\
\hline 1,250 & \multirow{3}{*}{ Archaic } & Late & A.D. 700 \\
\hline 3,500 & & Middle & 1500 B.C. \\
\hline 6,000 & & Early & 4000 B.C. \\
\hline 8,500 & \multirow{2}{*}{ Paleo-Indian } & & 6500 B.C. \\
\hline 11,950 & & & 9950 B.C. \\
\hline
\end{tabular}

The Paleo-Indian period in Northcentral Texas (ca. 9950-6500 B.C.) generally includes those remains of human presence that can be dated to the very late Pleistocene and the immediate postPleistocene periods (for reviews relevant to this period in Northcentral Texas, see Hofman 1989a; Johnson 1989; Prikryl 1990; Story 1990). Unfortunately, the Paleo-Indian occupation of the upper Trinity River basin is known primarily through diagnostic projectile points from surface collections or from stratigraphically mixed contexts (Meltzer 1987; Meltzer and Bever 1995). The Field Ranch site (X41CO10) along the upper Elm Fork is a prime example of typical site contexts (Jensen 1968). Based on a sample of projectile points from surface sites, Prikryl (1990) has suggested that the most common Paleo-Indian point types in this area are Plainview and Dalton. Ferring and Yates (1997) suggest that these types date to about 9,500-10,000 years ago, based on cross dating with other regions. The suggested age for these types may correspond to the onset of early Holocene alluviation in the Trinity River valley.

Clovis and Plainview points are commonly found along both Denton and Clear creeks in the Cross Timbers, northwest of Dallas. Until recently, the Lewisville Lake site (41DN71) was the best known Paleo-Indian site within the region, containing large burned features interpreted as hearths, and a low density of artifacts, including a Clovis point (Crook and Harris 1957, 1958, 1961). Although the original radiocarbon dates on the hearths suggested an anomalously early 
age for Clovis points (ca. 37,000 B.P.), subsequent work by the Smithsonian Institution (Stanford 1981) appears to have resolved the controversy concerning the date of the occupation. It appears that naturally occurring lignite, present in these hearths as either a fuel or as an inadvertent inclusion, contaminated the radiocarbon samples. Consequently, the usually accepted date of 12,000-10,000 B.P. for Clovis period occupations is probably a reasonable estimate for the first human occupation of Northcentral Texas.

A more spectacular exception to the generally limited data on Paleo-Indian sites in Northcentral Texas is the deeply buried Clovis-age Aubrey site (41DN479), located on the Elm Fork of the Trinity River north of Dallas (Ferring 1989, 2001). The discovery of this site, buried approximately 7-8 m below the top of the Elm Fork flood plain just below the Lake Ray Roberts dam, suggests that well-preserved Paleo-Indian sites in Northcentral Texas will only be found by examining deeply stratified Holocene alluvium in modern flood plain situations.

Despite the lack of extensive data relating to the early Paleo-Indian period in Northcentral Texas, some attempts have been made to generalize the settlement mobility and intensity of site occupation, drawing on what is known and on assumptions based on comparisons with other areas. For instance, a number of researchers have seen evidence for a high degree of group mobility in the broad distribution of Paleo-Indian artifacts over the landscape and in the variety of presumably nonlocal lithic raw materials from which the artifacts were made (Meltzer and Smith 1986; Shafer 1977; Story 1990:177). Likewise, the well-documented exploitation of megafauna by Paleo-Indians in the western United States, coupled with the known presence of similar animals in Northcentral Texas between 11,000 and 9,000 years ago (see Slaughter and Hoover 1963), has resulted in the popular (and logical) conclusion that big game hunting was part of the Paleo-Indian subsistence strategy in Northcentral Texas. The recent important excavations at the Aubrey site, however, have indicated that subsistence efforts did not focus on big game animals alone. Rather, the entire range of prairie and forest species was used by the occupants of the site, including bison, deer, rabbits, squirrels, fish, and abundant turtle (Ferring 1989; Ferring and Yates 1997). Interestingly, although mammoth remains are present, their exploitation has not been substantiated (Ferring and Yates 1997). Whether this pattern of a more generalized foraging subsistence system is characteristic of Clovis adaptations on the fringes of the Eastern Woodlands and the focus on now extinct, big game species is more characteristic of a Plains adaptation remains to be documented; but, Ferring and Yates (1997:5) suggest that, in general, the Clovis people probably employed "very flexible adaptive strategies.”

The Archaic period in Northcentral Texas is tentatively dated between 6500 B.C. and A.D. 700. As is true for many areas, a threefold division of the Archaic period, consisting of early, middle, and late subdivisions, has been applied in Northcentral Texas (Prikryl 1990, 1993). Thus, the Early Archaic has been dated from 6500 to 4000 B.C., the Middle Archaic from 4000 to 1500 B.C., and the Late Archaic from 1500 B.C. to A.D. 700. Relatively recent overviews that cover the Archaic in this portion of Texas include Hofman (1989a), Prikryl (1990), and Story (1985, 1990). Archaic remains are usually found in upland settings and are frequently mixed with later material. In fact, the initial treatment of the Archaic period in Northcentral Texas (Crook and Harris 1952, 1954), which defined the Carrollton and Elam foci, was based upon materials from such mixed terrace contexts. Consequently, these time-space constructs are no longer recognized as being acceptable for this area of Texas (Peter and McGregor 1988; Prikryl 1990; Yates and Ferring 1986). General trends that have been proposed as characterizing the Archaic period in 
Northcentral Texas include an increasing complexity of settlement systems, increasing population size and density, decreasing mobility, and the development of distinct group territories (Prikryl 1990; Story 1985:52).

During the Early Archaic (ca. 6500-4000 B.C.), in general, the occurrence of small and widely distributed sites has been suggested to be a reflection of high group mobility within large and poorly defined territories and of a generalized hunting-and-gathering economy (Meltzer and Smith 1986; Story 1985:35, 39). Unfortunately, Early Archaic occupations in Northcentral Texas are poorly documented, and no sites with isolable Early Archaic components are known in this area (Prikryl 1990). Based on surface collections, Prikryl (1990) hypothesizes a generalized hunting-and-gathering economy during this period, with high group mobility, a lack of regionalization, and "little in the way of recognized territorial boundaries" (Prikryl 1990:71). Projectile point forms that may be associated with the Early Archaic in Northcentral Texas include Early Split Stemmed and possibly Angostura (Prikryl 1990; Story 1990:Figure 31).

In comparison to the Early Archaic, the Middle Archaic period in Northcentral Texas (40001500 B.C.) is even less well known. Fewer sites are known with Middle Archaic components than for any other period, but the few surface collections available suggest the beginnings of regional cultural differences by the end of the period (Prikryl 1990). Diagnostic dart points that may be associated with the Middle Archaic include the Basal Notched group (which includes Calf Creek, Bell, and Andice), Wells, Dawson, Carrollton, and Bulverde (Prikryl 1990; Story 1990:Figure 31). An intact Middle Archaic component was identified at the Calvert site (41DN102; Ferring and Yates 1997) at Lake Ray Roberts and is summarized as follows:

Hearths, a burial, an unmixed assemblage of artifacts and fauna provide new evidence of adaptations to a drier Middle Holocene landscape. Artifact types are similar to those from adjacent regions (Story 1990) suggesting broad cultural interactions. The foraging economy emphasized procurement of small game and deer. It is assumed that these people were quite mobile, as repeated occupations of the site during the [Middle Archaic] period are evident [Ferring and Yates 1997:305].

Population density may have reached a peak during the Late Archaic period in Northcentral Texas (ca. 1500 B.C.-A.D. 700). Evidence for this can be found in an apparent increase in the number of Late Archaic sites, a greater distribution of sites over the landscape, and evidence of decreasing group mobility (Prikryl 1990). At the same time, interregional contact may have diminished. If greater spatial dispersal of sites is not a result of sampling error due to unequal destruction or burial of earlier sites, it may reflect an economic system making increasing use of all available floral and faunal resources. Throughout Northcentral Texas, Late Archaic period occupation sites are relatively common in the uplands, and a relatively large number of buried sites are also known from the Trinity River flood plain (Ferring 1990:51). Dart points that may be diagnostic of the Late Archaic include Castroville, Marshall, Edgewood, Ellis, Trinity, Palmillas, Yarbrough, Dallas, Godley, Elam, and Gary (Prikryl 1990; Story 1990:Figure 31).

Investigations at Joe Pool Lake (Peter and McGregor 1988) and Lake Ray Roberts (Ferring and Yates 1997) indicate that remains of the Late Archaic period are characterized by assemblages apparently left by small bands of foraging hunters and gatherers who occupied a locality for a limited time period and then moved to another locality. These sites were apparently reoccupied numerous times on a seasonal basis. Faunal remains indicate that Late Archaic populations 
exploited a mix of prairie, forest, and riparian species and that white-tailed deer, rabbits, turtles, and mussels were primary food resources (Ferring and Yates 1997:6). In summarizing the results of investigations at a number of Late Archaic sites at Lake Ray Roberts, Ferring and Yates (1997:305) state:

The most substantial occupations of the project area took place in the later part (post-3,000 yr bp) of the [Late Archaic] period. This is clearly a broad regional trend . . . although poor site exposure limits our understanding of earlier periods. Late Archaic sites here uniformly register mobile foragers that exploited all habitats available to them. Residential mobility . . . is implied. Repeated occupations at multiple sites were characterized by use of rock-lined and unlined hearths. On stable surfaces these are recorded as rock middens. In aggrading environments, discrete hearth construction events are clear. Import and curation of chert tools is evident, and contrasts with core-biface curation in the [Middle Archaic] period. Chert was preferentially used for straight, expanding and corner-notched points, while local raw materials were reduced on-site and dominate the contracting-stemmed forms. Despite quite good resource availability, dietary stress is recorded from skeletal and dental analyses....

The documentation of large pits associated with Late Archaic period sites in the Richland Creek and Chambers Creek drainages (Bruseth and Martin 1987) also suggests that important sociopolitical changes may have been occurring during this time period. Unfortunately, the significance of these pits remains an enigma despite their excellent documentation.

The beginning of what is called the Late Prehistoric period in the upper Trinity River basin (ca. A.D. 700-1700) is marked by the initial appearance of arrow points. The A.D. 700 date for the start of this period is based upon dated contexts for similar material in the Brazos River drainage to the west. Both Lynott (1977) and Prikryl (1990) have proposed that the Late Prehistoric period be divided into an early and a late phase, with the early phase reflecting a continuation of the foraging subsistence system of the preceding Late Archaic period and the late phase reflecting Southern Plains influences. In this view, the early phase dates between A.D. 700 and 1200 and is characterized by sand- and grog-tempered ceramics and Scallorn, Steiner, Catahoula, and Alba arrow points (Lynott 1977; Prikryl 1990). The late phase dates from A.D. 1200 to 1700. It is associated with the appearance of shell-tempered Nocona Plain ceramics, various unstemmed triangular points (e.g., Maud, Fresno, Harrell, and Washita), and Perdiz points (Lynott 1977; Prikryl 1990). Evidence of horticulture and bison procurement also appears in sites of this period (Harris and Harris 1970; Morris and Morris 1970).

As a result of intensive excavations at the Cobb-Pool site (41DL148) at Joe Pool Lake, Peter and McGregor (1988) proposed a reformulation of the Late Prehistoric period. The Cobb-Pool site yielded house structures, roasting pits, Alba points, grog-tempered ceramics, and charred corn cupules. Radiocarbon dates from several features indicate the site was occupied during the late twelfth or early thirteenth century. Present evidence suggests that the site does not represent an intrusive Caddoan occupation; consequently, a significant adaptive change appears to have occurred, in at least some areas, during a middle phase of the Late Prehistoric period. It is also likely that ceramics were not introduced to the region before this time.

In regard to the Late Prehistoric components investigated at Lake Ray Roberts, Ferring and Yates (1997:305) summarize the results of that research as follows: 
There are no woodland-like sites in north-central Texas, suggesting that Plains Woodland influence/contact did not characterize the transition to the Late Prehistoric period. No ceramics were found with [Late Prehistoric I] assemblages, which have Scallorn, Alba and small Gary points. These appear to be shortterm occupations that took place under conditions of reduced precipitation compared to the Late Archaic. Except for the replacement of darts with bow-arrow weaponry, these occupations are essentially similar to the Late Archaic. Regional exchange of technological information, rather than environmental change, probably is the factor behind the [Late Archaic] to [Late Prehistoric] shift.

Late Prehistoric II occupations are characterized by multiple, short-term use of probably logistic sites which lack ceramics and architecture. The architectural remains at 41DN102 are the only ones in the project area. At best, this was a small hamlet, occupied ca. 500-650 yr bp. No evidence of horticulture was recovered, and the [Late Prehistoric II] faunas indicate a foraging strategy that emphasized deer procurement, and occasionally bison as well. Transport and curation of chert raw materials was about as frequent as in the [Late Archaic], and long-distance raw material acquisition (e.g., Edwards, Alibates) is not evidenced. Ceramic traditions are dominated by locally produced shelltempered wares, which by this time were being produced in the Southern Plains region generally. As recorded by previous synthesis (Story 1990) little if any interaction with the Caddoan area is indicated. Thus, the Ray Roberts prehistoric data suggest that regional traditions emerged at the end of the [Late Prehistoric] period largely independent of the Plains or East Texas Woodlands.

More recently, McGregor (personal communication 1999) has argued strongly for a "middle subperiod" of the Late Prehistoric that he dates between A.D. 1000 and 1350 . He believes that arrow points with straight or rectangular stems are most diagnostic of this period and identifies three sites or site areas with relatively clean (or minimally mixed) components of this middle subperiod-the Cobb-Pool site (41DL148), Area B at the McDonald site (41HI105) on Hackberry Creek in the middle Brazos River drainage, and Area F at the Haley's Point site (34MA15) on the Red River (Brown et al. 1987; Peter and McGregor 1988; Rohn 1998). McGregor also notes that maize is common at Haley's Point, as it is at Cobb-Pool, and suggests that these sites are representative of a relatively short-lived, region-wide subsistence pattern involving a partial dependence on agriculture during this middle subperiod (McGregor, personal communication 1999).

Although no one can dispute the presence of domesticates at Cobb-Pool and Haley's Point, the lack of any evidence for Late Prehistoric agriculture at Lake Ray Roberts and Lewisville Lake leaves open the question of how extensive and how early this agricultural pattern was. Maize agriculture is known to have been present at Late Prehistoric sites along the East Fork, based on the recovery of maize from the Hogge Bridge, Butler Hole, and Campbell Hole sites earlier during this century (Stephenson 1952a:305), but the dating of these remains has always been uncertain (Prikryl 1990:77). As late as 1993, the available data allowed Fritz (1993:241) to state that, apart from Cobb-Pool, Late Prehistoric sites in Northcentral Texas seemed to show a generalized adaptation in which the most important plant foods were nuts, wild seeds, fruits, and the problematic, possible tuber that might be a species of Psoralea. Since then, several small projects have shed additional light on the introduction of maize horticulture into Northcentral Texas. The Harbor Pointe site (41DL369), located on Rowlett Creek (a tributary of the East Fork of the Trinity River), yielded remains of at least four individuals dated by AMS analysis of bone collagen to cal. A.D. 1010 (1035) 1165. No pottery was recovered with these remains, although shell beads and a shell gorget were present, and a stable carbon isotope ratio of -21.6\% indicates that the group's diet contained little or no maize (Cliff et al. 1996; cf. Lynott et al. 1986:Figure 2). More recently, a disturbed burial (41DL373), located on Spring Creek (a 
tributary of Rowlett Creek), was dated by AMS analysis of bone collagen to cal. A.D. 1155 (1220) 1275, with a stable carbon isotope ratio of $-17.8 \%$ o (Peter and Clow 2000). This value is similar to stable carbon isotope values believed to represent the initial introduction of maize agriculture in New York around A.D. 1000 (van der Merwe and Vogel 1977) and is comparable to values of $-18.0 \%$ to $-20.0 \%$ for initial maize-consuming Caddo populations in Arkansas (Rose and Hoffman 1989). Assuming that (1) these carbon isotope ratios directly reflect changes in the $\mathrm{C}_{4}$ plant contribution to the human diet (see Herz 1990 for a discussion of other possibilities), and (2) these burials are representative of more regional changes in prehistoric dietary patterns, then maize horticulture may have been introduced into Northcentral Texas around A.D. 1200.

Within Northcentral Texas, the time from A.D. 1700 to 1850 has been designated the Historic Indian period (Prikryl 1993). Prior to the founding of New Mexico in 1598, the European presence in the Southwest and on the Southern Plains was sporadic at best (Coronado in 15401541, the Rodriguez-Chamuscado party in 1581, Espejo in 1582-1583, etc.). After 1598, Spanish influence was never absent from the Southern Plains, although actual contact with Europeans continued to be limited and there are only brief records of journeys into or through the area (Hofman 1989b; John 1975). Despite this, it was not until the beginning of the nineteenth century that the physical presence of Europeans on the Southern Plains became commonplace. This was the result of increasingly peaceful relations between the Spanish in Texas and the Plains Indians to the north, and the acquisition of Louisiana by the United States in 1803. Prior to about 1725-1750, Apachean groups appear to have dominated the western portion of the Southern Plains, known as the High Plains; after this time, the area was increasingly controlled by the Comanche and Kiowa. On the eastern portion of the Southern Plains, within the area now known as the Lower Plains and Northcentral Texas, the Wichita tribes became dominant (Bell et al. 1967; Hofman 1989b:91).

Unfortunately, since good historical documentation is very sparse for the upper Trinity River basin during the early Historic Indian period, it is not clear which specific aboriginal groups were residing in the Dallas area at the beginning of this period. What is clear is that the early Historic Indian period in Northcentral Texas was a time of population fluctuation, movement, and amalgamation (see Newcomb 1993). Available data suggest that many, if not all, of the aboriginal occupants of the eastern margin of the Great Plains, including Northcentral Texas, were Caddoan language speakers, from the Arikara in the north to the Wichita and Kichai in the south. In this light, it is worth noting that it has also been suggested that the Socoatino, encountered by the survivors of the de Soto expedition in the sixteenth century, were Caddoan speakers and were the same as the Canohatino, identified by the French in the latter part of the seventeenth century, apparently located at that time "on the Blackland Prairies between the Guadalupe and Trinity rivers to the east of present-day San Antonio, Austin, and Waco" (Newcomb 1993:24). If the prehistoric occupants of the eastern margin of the plains in Texas were indeed Caddoan speakers, it would explain how they were absorbed very early by other Caddoan-speaking groups (such as the Yojuane, Kichai, Tawakoni, Taovaya, Iscani, and Wichita proper) who arrived in Northcentral Texas in the late seventeenth and early eighteenth centuries. Most of these groups, in turn, amalgamated to form the historic Wichita Tribe; however, some were probably absorbed by the united Caddo Tribes, and some may even have joined amalgamations of a variety of groups, such as the Tonkawa, during the late eighteenth and early nineteenth centuries. 
The Apachean group of most interest for the Lower Plains and Northcentral Texas was the Lipan, who inhabited the area from the upper Nueces and Medina rivers to the upper Colorado and Red rivers, also ranging into Mexico. The Spanish first encountered the Apache in the sixteenth century, and hostilities soon developed. The Apache acquired the horse around 1660 and this increased mobility made them even more dangerous to the Spanish (Webb and Carroll 1952:1:54-55). Beginning in the early eighteenth century, the Lipan Apache came under increasing pressure from the Comanche, who were at that time expanding into Texas. In an attempt to gain allies against these new enemies, some bands of Lipan made peace with the Spanish and asked that missions be established for them. One of these was San Sabá de la Santa Cruz, in present-day Menard County (Webb and Carroll 1952:1:55). The destruction of this mission by an alliance of Wichita and Comanche (collectively referred to as Norteños by the Spanish) in 1758, and the subsequent defeat of a punitive Spanish expedition with Apache allies under Diego Ortiz Parilla by the Wichita at Spanish Fort on the Red River in 1759 (John 1975:297-298, 350-352; Webb and Carroll 1952:1:55), can be taken as marking the ascendancy of the Wichita and Comanche on the Southern Plains. Subsequently, the Lipan Apache in Central Texas (in contrast to the western Lipan who ranged west of the Pecos River) were increasingly allied with the Europeans against the Western Apache (specifically, the Mescalero in Texas) and the Comanche. They negotiated a treaty of peace with Mexico in 1832, and aided Colonel John H. Moore's company of Texas Rangers in 1839 and Colonel John Coffee Hays's company in 1841 against Indians on the frontier. They participated in general Indian treaties with the Republic of Texas in 1844 and with the United States in 1846. Finally, the remaining eastern Lipan merged with a band of Tonkawa and were removed to Indian Territory in October 1848 (Webb and Carroll 1952:1:55).

The term "Wichita" has been used to refer to a group of linguistically related tribes, including the Wichita, Taovaya, Tawakoni, Iscani, Waco, and Kichai. Many of these groups apparently entered the Southern Plains in the seventeenth century, probably from Kansas and southern Nebraska, to escape the hostilities by the Osage (Webb and Carroll 1952:2:904). The Wichita were true Plains Villagers, with an economy that was jointly dependent upon agriculture and bison hunting. They occupied permanent villages of beehive-shaped, grass houses, from which they conducted seminomadic bison hunts. In 1719 their villages were located along the Arkansas River in northern Oklahoma (Hofman 1989b:95). By 1750, they had moved some of their villages to southern Oklahoma, along the Red River. Others were located on the upper ends of the Sabine and Neches rivers in Texas and subsequently on the middle Trinity and upper Brazos rivers. In 1772, the year they concluded a nominal peace with the Spanish, one of their villages was on the Salt Fork of the Brazos, on the Lower Plains west of Dallas (John 1975:Map 3; Webb and Carroll 1952:2:705). Wichita groups were included in treaties made with the Republic of Texas in 1843 and with the United States in 1837 and 1856 (Webb and Carroll 1952:2:709). In Texas they continued to live between the upper Brazos and Trinity rivers until 1855. In that year, the Tawakoni and Waco were placed on the Brazos Indian Reservation, south of Fort Belknap, in company with a number of other Native American remnant groups (Smith 1996; Webb and Carroll 1952:1:212; 2:905). Subsequently, as a result of increasing animosity from white settlers, they were removed to Indian Territory in 1859 (Smith 1996; Webb and Carroll 1952:1:210). The remnants of the Wichita moved to Kansas during the Civil War, but returned to Oklahoma after the war to settle permanently near present-day Anadarko (Hofman 1989b:95). 
The Comanche are a Shoshonean group who originally resided along the upper Yellowstone and Platte rivers. About the beginning of the eighteenth century, they left these areas and began to migrate onto the Southern Plains, where they drove a wedge between the Apache to the west (driving them farther south and west) and the Pawnee and Wichita to the east. By the early nineteenth century, their range was at its greatest extent, stretching from central Kansas to Austin and from Oklahoma City westward to Raton Pass in New Mexico. The most important divisions of the Comanche consisted of the Yamparika (Root-eaters), who ranged along the Arkansas River; the Kotsoteka (Buffalo-eaters), who were just to the south of the Yamparika; the Nokoni (Wanderers), who occupied the territory along the Red River; the Quahadi (Antelope People), located on the High Plains; and the Penateka (Honey-eaters), who were the southernmost Comanche group in Texas, living on the fringe of the East Texas timber belt (Webb and Carroll 1952:1:385, 2:358). Their earliest known raid in Texas was in 1758, when they helped in the destruction of the mission of San Sabá (see above); and for the next 117 years, they waged intermittent warfare against first the Spanish, then the Mexicans, the Texans, and finally the United States (Webb and Carroll 1952:1:385). The Comanche were nomadic Plains hunters, whose lifestyle depended upon the bison as a source of meat and raw material for clothing, shelter, etc., and upon the horse as a means of hunting and transport. The Comanche were signatories to the Medicine Lodge Treaty with the United States in 1867, in which they agreed to cede all of their territory except for a 5,546-square-mile reservation in southwestern Oklahoma. Following a general uprising of the Comanche and Kiowa in 1874, they were defeated by the U.S. Army in 1875 and permanently confined to their Oklahoma reservation (Webb and Carroll 1952:1:385).

The Kiowa are a Tanoan group who may have moved onto the Southern Plains from the headwaters of the Yellowstone and Missouri rivers in what is now Montana (Hays 1989:255). Prior to 1790, the Kiowa and Kiowa-Apache were intermittently at war with the Comanche, and the Kiowa actually may have been responsible for pushing the Comanche out of the Black Hills area and onto the Southern Plains. Then in 1790, they made a lasting peace with the aid of the Spanish and were allied thereafter (Wallace and Hoebel 1952). Like the Comanche, the Kiowa were nomadic bison-hunters, with no permanent villages, agriculture, or pottery. The Kiowa were divided into six or seven semiautonomous bands (including the Kiowa-Apache) and generally occupied western Oklahoma and the Texas Panhandle. The first regular trading contact with the Americans began in 1834, and the first treaty with the United States was signed in 1837. Following a general uprising of Plains Indians in 1864, the Kiowa signed the Medicine Lodge Treaty in 1867, committing themselves to life on a reservation in southwestern Oklahoma. Intermittent raiding continued into Texas for the next seven years and the Kiowa finally were confined permanently to a reservation in 1875 (Webb and Carroll 1952:1:964-965).

Archeological remains that can be associated with these early historic groups are rare compared to the remains of earlier periods. Within the upper Trinity River basin, and in Dallas County itself, little evidence of these historic Indian groups has been found, with the exception of a few Native American sites with European items (Sollberger 1953). In actuality, all of these groups are better represented in the regions surrounding the upper Trinity River valley.

To the northwest of Northcentral Texas, a series of unexcavated sites in Custer, Canadian, and Caddo counties, Oklahoma, forms the basis of what has been defined as the Wheeler complex (Bell and Bastian 1967; Hofman 1984:355-357). These sites all have triangular arrow points 
(i.e., Fresno), large plano-convex end and side scrapers, expanding base drills, and a dark sandy paste pottery referred to as Edwards Plain. They also contain abundant remains of bison and a few artifacts of Southwest origin, including Glaze paint ware, obsidian, and turquoise. The early historic age of the sites is demonstrated by a limited number of European trade goods (including beads) and possible native-made gunflints (Hofman 1989b:95-96). Cross dating with the Southwest material indicates that these sites date between A.D. 1650 and 1725 . The ethnic affiliation of the occupants of the Wheeler complex sites is presently unknown, but they may have been either Wichita-related or Apachean groups (Hofman 1989b:96-97).

Farther west, another series of sites in western Oklahoma has been grouped together as the Edwards complex (Hofman 1984:348-354, 1989b:97-98). These sites are believed to date between about A.D. 1400 and 1650, and may be associated with fortifications and apparent posthole structures. The artifact assemblage is dominated by small, triangular arrow points (i.e., Fresno) and the sandy paste Edwards Plain pottery. Other artifacts include expanded-base drills, small to medium-sized end and side scrapers, bone awls and toothed fleshers, bone and shell beads, and possibly scapula hoes. Imported ceramics consist of both Caddoan and Puebloan wares (Hofman 1989b:97). The economy of these Edwards complex groups appears to have been focused heavily on bison hunting, and possibly on the trade of bison-derived products such as hides and dried meat (Hofman 1989b:98).

Sites that are believed to be of Apache origin have been identified along the border of the High Plains to the northwest along the Prairie Dog Town Fork of the Red River in Randall, Armstrong, and Briscoe counties, Texas (Hughes 1978; Katz and Katz 1976). These sites contain small, triangular arrow points and a thin, dark, plain, often micaceous, pottery that is apparently of local manufacture. The late dates for these sites are based on the presence of late Puebloan painted wares from New Mexico. To the west of this area, in Deaf Smith County, Texas, Hughes (1991:35) has defined a Tierra Blanca complex at the site of the same name. Use of the site is believed to postdate A.D. 1400, and it has yielded evidence of a tipi ring, a semisubterranean slab-lined circular structure, and a windbreak or small arbor (Hofman 1989b:99). The Tierra Blanca complex in general is suggested to date between A.D. 1400 and 1650. The sites are notable for the occurrence of Glaze paint wares and a dark utilitarian ware, as well as a low frequency of Garza and Lott arrow points. The former is a triangular point with a single basal notch, and the latter is a triangular point with an expanding stem and a central basal notch.

Farther south along the caprock, the Garza complex appears to be a late Apachean complex that includes Garza and Lott points and micaceous paste wares similar to those found in the north and to Perdido Plain and Tierra Blanca Plain. Sites that have been grouped under this name are located in Garza, Floyd, Crosby, and Lubbock counties, Texas, and possibly in Chaves County, New Mexico (Hofman 1989b:98-99). The complex is dated between A.D. 1500 and 1650, and characterized by an apparently heavy reliance on bison hunting, with little or no horticulture. The ceramic assemblage contains a high proportion of Southwest pottery, in addition to turquoise, obsidian, and marine shell beads. Sites that belong to this complex have been identified in the Justiceburg Reservoir area, in association with Pecos Glaze Polychrome V and Pecos Faint Striated (Boyd and Tomka 1990:260). 
Groups of the Wichita Confederacy, being Plains Villagers, have left much more substantial archeological remains. Numerous villages belonging to historic Wichita groups have been identified and investigated in Oklahoma, within Northcentral Texas, and along the boundary of Northcentral Texas and Northeast Texas (Bell 1984; Fox 1983:41-46). Based on excavations at the Pearson site in Rains County, Texas, due east of Dallas County, the NorteZo focus has been proposed for these historic Wichita components (Duffield and Jelks 1961). The most extensive archeological work has been done at several sites along the Red River in Texas and Oklahoma, near the present Texas town of Spanish Fort, northwest of Dallas County, which is believed by some to be the site of the village attacked by Parilla in 1759 (Bell et al. 1967). The excavations at the Longest site (34Jf-1) in Oklahoma documented the presence of a fortified enclosure and circular grass-covered lodges. Artifactual material recovered from these Wichita sites shows a mixture of artifacts of Native American manufacture and materials obtained in trade with the French or the Spanish. Artifacts of Native American manufacture include triangular arrow points (i.e., Fresno, Harrell, and Washita), thick end scrapers on flakes, diamond-shaped beveled knives, T-shaped perforators, bifacial gun flints, bison scapula hoes, pottery elbow pipes, and Womack Engraved pottery. Trade artifacts found to be present at Wichita sites include metal knives and knife handles; axes; splitting wedges; kettle fragments; awls; chisels; scissors; buttons; flintlock gun parts; bullets and shot; bridle parts; metal ornaments such as bells, finger rings, and bracelets; and numerous trade beads (Fox 1983:45).

The archeological remains of the Comanche and the Kiowa (and Kiowa-Apache) are even less identifiable than the other early historic Indian groups. Hays (1989:Table I-5) lists 41 selected Comanche, Kiowa, and Kiowa-Apache sites on the Southern Plains, at least 25 of which are historic burials or cemeteries. To the far west of Dallas County, one probable Comanche campsite of the late 1700s has been reported at MacKenzie Reservoir, in Briscoe County (Hughes and Willey 1978), and numerous probable Comanche burials have been located along the edge of the caprock. One of these, the Cogdell Burial, was found in a small niche or cave on the edge of the caprock (Word and Fox 1975). Artifacts recovered from the grave included clothing, such as a cotton shirt, beaded leggings, and other beaded garments; a pair of moccasins; fragments of wool blankets and a buffalo robe; brass bracelets; hair ornaments; a gold-plated finger ring; silver conchas; fragments of a weasel pelt; a small, rectangular hand mirror; trade beads; a fragment of a silver buckle; elk teeth and Pacific abalone shell pendants; and an iron hoe. Other materials present included wooden and leather saddle parts, iron saddle hardware, fiber cordage, portions of what may have been a Spanish bridle, the wooden poles and fasteners of a travois, and buffalo or cow bones that may have been the remains of a food offering (Fox 1983:47-48).

\section{Historic Background}

The first presence of Europeans in Northcentral Texas may have been in 1542, when the remnants of the de Soto expedition, led by Luis de Moscoso de Alvarado, entered modern Texas in an effort to find a land route to New Spain. Some researchers believe that the expedition crossed Northcentral Texas (Lebo and Brown 1990:61), although others place the route much farther to the east and south (Bruseth and Kenmotsu 1991; Chipman 1992; Hudson 1986;

Schambach 1989; Weber 1992). A consistent European presence in the region did not occur until the early 1700s, when French traders from Louisiana began to move westward along the 
Red River. The Spanish considered this French incursion to be a threat to the security of New Spain, and they responded by redoubling efforts to counterbalance the French influence with the Native Americans in East and Northcentral Texas. These efforts continued until 1763, when France ceded Louisiana to Spain under the Treaty of Paris. This treaty reduced the perceived threat to the security of New Spain and resulted in a reduction in Spanish investment in eastern and northern Texas. More important, from the Native American viewpoint, was the severe military defeat inflicted on the Spanish by Wichita and allied tribes at Spanish Fort on the Red River in 1759. It has been argued that this defeat put an end to Spanish military and missionary expansion to the north (Weddle 1964, 1965).

The first Americans to settle in the region were primarily from Arkansas Territory. The first permanent settlement in the Dallas area was Bird's Fort in present-day Tarrant County, established in 1840. Also in 1840, John Neely Bryan reconnoitered the Dallas area to determine its suitability for a trading post. By the time Bryan returned in 1842, troops of the Republic of Texas had removed the Native American groups with whom he had intended to trade. As a result, Bryan determined to found a settlement in the same area where downtown Dallas is today. To further this goal, Bryan invited the residents of Bird's Fort to join him in his new settlement. Five individuals (John and James Beeman, Captain Mabel Gilbert, Tom Keenan, and Isaac B. Webb) and their families decided to answer Bryan's call. Prior to this, in 1841, the Republic of Texas had contracted with the Texan Emigration Land Company to settle 600 families on a land grant encompassing portions of modern Dallas, Denton, Cooke, Collin, Grayson, Ellis, and Wise counties. This land grant became known as the Peter's Colony. The majority of the Peter's Colony settlers held property north of Dallas. The Peter's Colony continued until 1852, when disputes about land title between the Texan Emigration Land Company and the settlers came to a head and some of the settlers rose up in arms to defend their title to the land they had settled. Dallas County was organized from Robertson County in 1846, and Dallas served as the county seat (Works Projects Administration [WPA] 1992:38-50).

Texas was annexed by the United States in 1846 and some Dallas area residents joined the American army facing the Mexicans. The California gold rush in 1849 affected Dallas in two ways. First, Dallas was near a major trail for the "49ers" that used a ford across the Trinity River about seven miles to the north. Second, many Dallas area residents were struck with gold fever. Some, including John Neely Bryan, trekked to California, while others explored the nearby Wichita Mountains for gold (WPA 1992:46-47).

In 1855, another major colonizing venture was begun in the Dallas area when 200 French, Belgian, and Swiss immigrants arrived to found the utopian settlement of La Reunion, about three miles west of Dallas along the West Fork of the Trinity River. La Reunion was well funded, with initial capital of $\$ 600,000$, but the residents did not adapt well to frontier conditions and the colony never really prospered. Gradually the members of the colony drifted away, many becoming residents of Dallas. The colony officially dissolved in 1867 (WPA 1992:286-290).

Although present, slavery did not loom as large in the economy of the Dallas area as it did farther to the east. In 1846, there were 45 slaves in Dallas County, a number that grew to 207 by 1850 (Prince 1993:10). In the 1860 census, Dallas County had a total population of 8,655 people, of whom 1,074 were slaves (Prince 1993:16). Most of the white residents of the county were southerners by birth and supported the pro-slavery side of the abolition question. As passions 
grew during the election of 1860, a fire swept through the Dallas business district, destroying all but one building. This was immediately assumed to be an abolitionist plot, resulting in the hanging of three African-Americans, the flogging of the remaining African-Americans in the county, and the whipping and banishment of two white preachers from Iowa (WPA 1992:53-54).

Following the presidential election of 1860, Texas, in common with the rest of the South, began to consider secession. In a February 23, 1861, referendum on the issue, Dallas County voted 741 to 237 in favor of secession. Many county residents joined Confederate military units, and after a 516 to 3 vote on the issue, Dallas County donated \$5,000 in gold to the Confederate cause. The Dallas area provided foodstuffs to the Confederate Army, and in 1862 a small arms and ammunition factory opened in Lancaster, south of Dallas. Although the fighting never reached Northcentral Texas, the region was gradually impoverished by the war. Many of the commodities that were imported to the region became difficult to obtain and expensive; the price of food had risen between two and four times its 1861 levels by September 1863. The Dallas Herald was forced to cease publication between September 30, 1863, and July 2, 1864, due to a lack of newsprint. Following Lee's surrender, the Union Army occupied Texas, bringing news of the 1863 emancipation of slaves to Texas on June 19, 1865 (WPA 1992:55-58).

Although the Dallas area suffered economically in the aftermath of the Civil War, it was not as badly affected as other areas of the former Confederacy. This greater economic vitality was fueled in part by streams of immigrants from the rest of the country, who were hoping to make a fresh start in the as yet unsettled West. Other elements in the economy included Dallas's location near one of the cattle trails to Kansas and its role as a center of the buffalo hide market. In 1872, the Dallas economy received a major boost when the Houston \& Texas Central Railroad reached the city from the south, and in 1873, the Texas \& Pacific Railway provided important access to points east. After the arrival of the railroads, Dallas began to acquire many of the trappings of a major city, including the beginning of a water distribution system in 1873, gas lighting in 1874, a private telegraph company in 1875, telephones in 1880, and electricity in 1882 (WPA 1992:60-70).

An early dream of the Dallas business community was to gain water transport along the Trinity River. The problems associated with this effort included the seasonal fluctuations in the level of the Trinity River, as well as the many snags and rafts that had to be removed. The first effort in this respect occurred in 1866, when the state legislature chartered the Trinity Slack Water Navigation Company to provide the improvements required for navigation from Galveston to Dallas. Under the terms of the charter, the company was to receive 5,000 acres of public land for every lock and dam completed. Unfortunately, the company never started work on the project. In 1867, Captain J. M. McGarvey agreed to bring his Job Boat No. 1 from Galveston to Dallas. The journey required seven months, with much of the time being spent removing obstructions from the river channel. Although Captain McGarvey claimed that the upper Trinity was superior to both the upper Red River and the upper Mississippi River, his proposal to provide regular service to Dallas did not prove practical. Following his arrival, construction began in Dallas on the steamer Sallie Haynes, which made three trips downriver before being sunk. No records exist, however, of the Sallie Haynes ever making the voyage all the way to Galveston. 
After the railroads arrived in Dallas, interest in river navigation began to wane. Although several small steamers continued to ply the Trinity, some of which are thought to have made the trip from Galveston to Dallas, the use of the river as a significant thoroughfare for the shipment of goods and passengers essentially came to an end. In 1881, the state government was asked for $\$ 75,000$ to remove obstructions from the river. During the 1890s, interest in Trinity River navigation revived, and the Trinity River Navigation Company was formed in 1891. The company built two steamers, Dallas and The Dallas, and purchased the H. A. Harvey, Jr., in New Orleans. The Harvey made its way up the river in 1893, arriving in Dallas on May 13. A dam was built at McCommas Bluff to provide sufficient water for the steamer, and it spent the next few years carrying cargo between Dallas and the dam. In 1898, the Harvey and the remains of Dallas were sold to a Galveston firm, and the Harvey made a four-month voyage downriver to Galveston. In 1899, the U.S. Army Corps of Engineers submitted a plan to construct 37 locks and dams between Dallas and the Gulf of Mexico, permitting navigation of the Trinity River for eight months of each year. The plan went on to suggest that if a series of artesian wells were to be dug along the river channel, adding to the water flow, year-round navigation would be possible. In 1902, Congress appropriated $\$ 750,000$ to improve the Trinity River, with another $\$ 500,000$ being appropriated in 1904-1905. In addition, the citizens of Dallas contributed $\$ 66,000$ for the construction of a dam at Parson's Slough, 26 miles below the city. Nine locks were built before the beginning of World War I. In 1916 the project was reevaluated, with a new estimate of another $\$ 13$ million and 15 years being required to complete the project. Finally, in 1921, the U.S. Army Corps of Engineers recommended that any efforts to make the Trinity navigable above Liberty were impractical and should be abandoned.

In 1930, renewed interest in river navigation led to the creation of the Trinity River Canal Association, which in turn sponsored the creation of the Trinity Watershed Soil Conservation and Flood Control Association in 1936. These two organizations later merged to become the Trinity Improvement Authority (TIA). In 1955, the State of Texas created the Trinity River Authority (TRA). Lobbying on the part of the TIA and TRA led to passage of the Trinity River Basin Bill in 1963; but the bill merely authorized the project and contained no funding. Due to the huge backlog of river and harbor improvement projects approved by Congress, no funding was ever appropriated for this project. The dream of a navigable Trinity River once again died in 1979, when the U.S. Army Corps of Engineers again determined that navigation of the Trinity River upstream of Liberty was not economically feasible (Jadrosich 1996; McElhaney 1995; Saunders 1991).

The history of Dallas is punctuated with several severe floods, with the floods of 1844, 1858, 1866, 1871, 1890, 1908, and 1913 being particularly memorable. In 1908, a devastating flood occurred along the Trinity River, with the river cresting at 51.3 feet. The flood caused tremendous property loss, estimated at $\$ 2,500,000$, and left 4,000 people homeless. The flood shut down the Dallas and Oak Cliff water systems and caused the collapse of the Texas and Pacific Railroad trestle across the Trinity, as well as threatening several other bridges. Following the 1908 flood, the city of Dallas determined to try to reduce the impact of Trinity River flooding. This led to the construction of the Houston Street Viaduct, a 5,106-foot-long concrete bridge constructed to ensure communication between Dallas and Oak Cliff even in the event of a major flood. A series of severe floods in the early 1920s led to renewed interest in flood control projects on the part of the local government. In 1926, the Dallas County Commissioners created the City and County of Dallas Levee Improvement District, which formulated the Ulrickson Plan 
for flood control. This plan called for the construction of levees, straightening and moving the river channel, additional viaducts, storm water drainage, and other improvements. In June 1928, ground was broken for the Trinity River levee and reclamation project (WPA 1992:414). The project involved the movement of 21 million cubic yards of earth from 1928 to 1932 (Baker 1988:47-48; Dooley 1988:92; McElhaney 1995:53). Funds in excess of $\$ 15,000,000$ were provided for the project by the Levee Improvement District, the city and county of Dallas, and affected utilities and railroads. Among these improvements were the Cadiz Street Viaduct (completed in 1932), the Corinth Street Viaduct (completed in 1933), and the Lamar-McKinney Viaduct (completed in 1934; Skinner, Whorton, and Trask 1996:18; WPA 1992:85, 94-96, 154156).

By 1900, Dallas had become a major commercial and manufacturing center and, with a population of 42,638, was the third largest city in Texas. Dallas's Love Field and Camp Dick (at the State Fairground) served as training bases for aviators during World War I. In the 1920s, the Ku Klux Klan became a factor in local politics, achieving particular importance between 1921 and 1924. Dallas's first radio station, WRR, was established in 1921, originally as a means of broadcasting emergency messages to the fire department. By 1927, WRR had become a commercial station. Beginning in 1930, Dallas began to be severely impacted by the Great Depression (WPA 1992:80-97, 266-267).

The economy of Dallas, and of the nation as a whole, did not begin to recover from the Depression until the mobilization for World War II began. After the war, the Dallas economy continued to grow along with the rest of the nation. Dallas's image was shattered by the Kennedy assassination on November 22, 1963, and it took many years to recover from this blow. A major economic downturn occurred in the late 1980s, when a drop in oil prices and the collapse of the real estate market dealt a severe blow to the Texas economy. This forced the Dallas region to diversify economically, investing heavily in the modern high-tech industries. 
Geoarcheological Investigations of Wetland Cell D within the Dallas Floodway Extension Project Area, Dallas, Texas 


\section{CHAPTER 3 METHODOLOGY}

Given the position of the project area within the Trinity River flood plain and the previous data collected immediately downstream and upstream through the previous test excavations of six archeological sites (Buysse 2000), it was determined that the potential for near-surface archeological deposits would be limited. Therefore, the research strategy was to systematically place backhoe trenches across the proposed impact area to determine the nature of the flood plain deposits and the potential for archeological deposits. The previous investigations of four sites (41DL337, 41DL338, 41DL355, and 41DL356) located west of I-45 on the northeast side of the Dallas Central Wastewater Treatment Plant and two sites (41DL318, 41DL319/357) located east of I-45 and south of the location of Wetland Cell D indicated that archeological site contexts are present within the immediate vicinity. To the west, however, site contexts had been disturbed by the construction and covering of sludge pits related to the wastewater treatment plant, while to the east, site contexts were buried within the West Fork paleosol more than a meter below the present flood plain surface. The swelling and contraction of the clay sediments, however, resulted in site contexts with little contextual integrity. Nevertheless, detection of potential buried sites with contextual integrity within Wetland Cell D was dependent upon the use of backhoe trenches.

Vegetation proved to be a limiting factor for the placement of trenches within the project area. In order to avoid excessive destruction of the dense flood plain vegetation, only six transects were cleared into the project area from the side nearest the I-45 bridge. Only young, green ash trees less than six inches in diameter were cleared with the aid of a tracked endloader. This approach resulted in the excavation of 10 backhoe trenches (see Figure 2), each $70 \mathrm{~cm}$ in width, $5 \mathrm{~m}$ in length, and varying in depth from 2 to $3 \mathrm{~m}$. An archeologist examined the soil for artifacts as each bucket was deposited on the ground. A geoarcheologist examined the soil matrix, provided descriptions of the sediments, and characterized the soil horizons. 
Geoarcheological Investigations of Wetland Cell D within the Dallas Floodway Extension Project Area, Dallas, Texas 


\section{CHAPTER 4 GEOMORPHOLOGY}

\section{INTRODUCTION AND GENERAL GEOMORPHOLOGY}

The fieldwork for the present investigation consisted of the excavation of 10 backhoe trenches within the limits of Wetland Cell D located in the proposed Dallas Floodway Extension (see Figure 2). Wetland Cell D is located east of the Dallas Water Treatment Plant in a triangularshaped wedge of the Trinity River's flood plain. This "triangle" is bordered on the west by I-45, and the other sides are formed by the current channel of the Trinity River. Much of the study area is covered in thick forest with minor amounts of open grassy areas. Its surface is relatively flat although there is a moderately large, west-to-east-trending stream channel in the area of backhoe trenches (BHTs) 6 and 10 and a large, gentle depression reminiscent of an old meander channel or slough in the area of BHTs 2 and 4.

The near-surface geology of the study area consists of Quaternary-age clays, silts, sands, and gravels of alluvial origin resting unconformably on Cretaceous bedrock. The Cretaceous bedrock in this region consists of the chalks and marls of the Austin Chalk overlying the dark blue-graygreen marine shales and claystones of the Eagle Ford Shale. The Austin Chalk ranges in thickness from 100 to $150 \mathrm{~m}$; the Eagle Ford Shale in this area ranges from 60 to $90 \mathrm{~m}$ in thickness (Bureau of Economic Geology 1972). Both of these formations dip gently to the southeast into the East Texas Embayment. Because of this dip, the Eagle Ford Shale outcrops or subcrops beneath the Quaternary north and west of the study area while the Austin Chalk underlies the Quaternary-age deposits within the study area.

This portion of the Dallas Floodway has been heavily modified over the past 150 years by dredging, modifications to the Trinity River's channel, borrow pit operations, highway and bridge construction, excavation of stormwater runoff channels, operation of landfills and trash dumps, digging and filling of sludge pits and ponds, and similar activities. Because of this, little is preserved of any surface fluvial structures related to earlier river channels that may have once been present on this portion of the Trinity River flood plain. Such absent structures include cutoff meanders (i.e., oxbow lakes), levee ridges, or abandoned river channels that predate the current Trinity River channel. West and north of the study area, above where the West and Elm forks join to form the main stem of the Trinity River, the river is deeply entrenched and very 
sinuous. The river valley is $3 \mathrm{~km}$ or more in width and there is considerable evidence that the river has avulsed repeatedly in the recent past (this is particularly true of the West Fork). Below the confluence of the West and Elm forks, the Trinity's flood plain grows progressively narrower. This narrowing is undoubtedly caused by changes in the underlying bedrock from the easily eroded shales of the Eagle Ford to the west and north to the more resistant chalks of the Austin Chalk to the south and east. In the immediate vicinity of Cell D, the current flood plain of the Trinity is just under $1 \mathrm{~km}$ in width and is bordered by prominent fluvial terraces of late Pleistocene to middle Holocene age (Cliff et al. 1998:Figure 8). This would indicate that for at least the past several thousand years the main stem of the Trinity has been confined to a very narrow belt. The narrowness of the flood plain in this area may also help account for the lack of preservation of earlier fluvial features. The confinement of the Trinity within a belt this narrow would also have an extremely negative impact on the preservation of earlier deposits in the upper 5 to $10 \mathrm{~m}$ of valley fill in this area.

The alluvial stratigraphy, soils stratigraphy, and geomorphology of the upper Trinity River have been investigated in a variety of studies. Ferring (1990) summarizes the history of geomorphic investigations and provides a working stratigraphic framework that can be applied to the Dallas Floodway. Details of alluvial stratigraphic units and paleosol stratigraphy can vary within the Trinity River valley; however, lithostratigraphic properties, cross-cutting relationships, and superposition of stratigraphic units allow for a general correlation to Ferring's (1990) stratigraphy model. General elements of the Ferring (1990) Trinity River model are summarized below for comparison to the newly acquired data from the Dallas Floodway.

Ferring (1990) recognized three terraced Pleistocene stratigraphic units and five flood plain stratigraphic units of Late Pleistocene to modern age in the upper Trinity River basin. Terraced units are, in order of decreasing age, Irving, Coppell, and Tioga alluvium. Geomorphic position, horizontal distribution, lithologic properties, and upper bounding paleosols are included as criteria for unit differentiation. Units beneath the flood plain include, also in order of decreasing age, Carrollton, Aubrey, Sanger, Pilot Point, and Recent alluvium. General stratigraphic properties of these units in their type areas are summarized in Table 2.

In comparing the Ferring (1990) model to the data from the Dallas Floodway, technical and logistical considerations must first be addressed. The correlation of the alluvial stratigraphic units by lithostratigraphic properties and relative stratigraphic positions allows for the development of a general correlation scheme. The paleosols at the top of each alluvial unit are implicit in Ferring's (1990) model; however, it does not require that paleosols exist at all localities or that they possess all properties described in their type areas where they do exist. First, there is inherent variability in an individual paleosol, and second, there are possible upstream to downstream variations in properties over the distances involved from the type areas to the Dallas Floodway.

That is to say, these alluvial units are not time stratigraphic or lithostratigraphic units in the true geologic sense. Each alluvial unit was not deposited at nearly the same time or under the same conditions everywhere it is present. The Pilot Point alluvium provides an excellent example of this. The Pilot Point is the name given to all the fluvial alluvium along the upper Trinity River younger than 4,500 years old (see Table 2). In many areas, it is a clay-rich deposit capped in the dark, cumulic West Fork paleosol (the flood basin facies of Ferring 1990). In others, it contains 
Table 2

Lithologic Properties, Depositional Environments, and Inferred Ages of Alluvial Stratigraphic Units in the Upper Trinity River

(based on Ferring 1990, 1995; Humphrey and Ferring 1994)

\begin{tabular}{|c|c|c|c|}
\hline Alluvium & Lithology & Depositional Environments & Inferred Age \\
\hline Recent & $\begin{array}{l}\text { Silt and clay grading to } \\
\text { sand and gravel }\end{array}$ & $\begin{array}{l}\text { Meander belt alluvium, } \\
\text { abandoned channel fill }\end{array}$ & Alluviation $<200$ years \\
\hline Pilot Point & $\begin{array}{l}\text { Silt and clay grading to } \\
\text { sand and gravel }\end{array}$ & $\begin{array}{l}\text { Meander belt alluvium, } \\
\text { overbank veneer over older } \\
\text { alluvium }\end{array}$ & $\begin{array}{l}\text { Alluviation and soil formation } \\
\text { from } 4,500 \text { years to present }\end{array}$ \\
\hline Sanger & $\begin{array}{l}\text { Calcareous silt and clay; } \\
\text { grades to sand and gravel }\end{array}$ & Meander belt alluvium & $\begin{array}{l}\text { Alluviation from } 11,000 \text { to } 7,500 \\
\text { years, } \\
\text { soil formation from } 7,500 \text { to } \\
4,500 \text { years }\end{array}$ \\
\hline Aubrey & $\begin{array}{l}\text { Bedded sand and gravel, } \\
\text { finer-grained alluvial } \\
\text { marls and lacustrine } \\
\text { sediment }\end{array}$ & $\begin{array}{l}\text { Channel, abandoned channel } \\
\text { fill, lake plain }\end{array}$ & $\begin{array}{l}\text { Alluviation }>15,000 \text { years } \\
\text { ( } 25,000 \text { ? to } 15,000 \text { years), } \\
\text { soil formation from } 15,000 \text { to } \\
11,000 \text { years }\end{array}$ \\
\hline Carrollton & $\begin{array}{l}\text { Loamy sediment grading to } \\
\text { sand and gravel }\end{array}$ & Meander belt alluvium & $\begin{array}{l}>15,000 \text { years } \\
\quad \text { (ca. 25,000 years?) }\end{array}$ \\
\hline $\begin{array}{l}\text { Coppell, Tioga, } \\
\text { Irving }\end{array}$ & $\begin{array}{l}\text { Loamy sediment to sand } \\
\text { and gravel }\end{array}$ & Channel belt alluvium & $>30,000$ years \\
\hline
\end{tabular}

deposits with a significant amount of coarser clastics (silt, sand, and gravel) which often exhibit fining-upward sequences typical of fluvial point bar deposits (the meander belt facies of Ferring 1990). This complex picture is made even more complicated by the fact that the West Fork "paleosol" forms the surface unit in some areas and is continuing to accumulate in those localities while it is buried by up to 2 to $3 \mathrm{~m}$ of more recent Holocene alluvium in others (Cliff et al. 1999:Figures A-20 and A-21). Since in most cases, the deposits covering the West Fork contain historic-age artifacts and debris, it is tempting to subdivide the Pilot Point into a historic and a prehistoric component. Further, there are often cross-cutting relationships between the two main "facies" of the Pilot Point (see Cliff et al. 1999:Figures 12 and 16).

Stratigraphic data collected for the Dallas Floodway Extension project have provided information on the lithologic, pedologic, and geometric properties of flood plain sediments immediately downstream of the Dallas Floodway (Figure 5; Cliff et al. 1998, 1999). Sediments associated with the various flood plain depositional environments recognized within the Dallas Floodway Extension project area were found to have distinctive lithologic and pedologic properties that allowed for their differentiation. A conceptual cross section (Figure 6) illustrates the geometric relationships between alluvial units identified in the Dallas Floodway Extension area. 
Geoarcheological Investigations of Wetland Cell D within the Dallas Floodway Extension Project Area, Dallas, Texas

\section{Figure}

5. Geomorphological map of a portion of the Dallas Floodway and proposed extension (after Cliff et al. 1998:Figure 8) 
Figure

6. Conceptual geological cross section of the Trinity River valley in the Dallas Floodway Extension area

Alluvial deposits are inset into Cretaceous bedrock and Pleistocene terrace Coppell/Tioga alluvium. Pilot Point, Sanger, and Aubrey/Carrollton alluvia are the units beneath the present flood plain. Stratigraphic units are adapted from Ferring (1990) (from Cliff et al. 1998). 
Pilot Point alluvium is typically the first mappable unit encountered below the flood plain surface in the Trinity Floodway Extension area (Cliff et al. 1998). Recent alluvium locally covers this unit near the present Trinity River channel, and recent overbank deposits may be locally included in Pilot Point overbank veneer deposits. Pilot Point alluvium is characterized as a black to dark gray (10YR $3 / 1$ to 5/2) silty clay loam to silt loam. In channel belt areas, it grades downward to loamy or sandy textures; whereas, outside of channel belts, it veneers older alluvial units. The unit commonly has either an A-Bt-C or A-Bw-C horizon sequence. Plant root activity and other bioturbation are the most common pedogenic processes. Pedogenic properties and stratigraphic position correlate to the West Fork paleosol identified by Ferring (1990). In channel belt areas, the soil profile grades to stratified alluvium; however, outside channel areas, the base of the soil can be mixed with underlying alluvium.

Sanger alluvium occurs beneath the Pilot Point alluvium in most locations in this area, except where it has been eroded by Pilot Point alluvium (Cliff et al. 1998). This unit is characterized as a brownish (10YR 6/4) calcareous silt loam with yellowish (10YR 6/6) mottles that commonly grades downward to channel belt sand or sand and gravel. The base of the Sanger alluvium rests either on older Aubrey/Carrollton alluvium or on Cretaceous bedrock. The unit commonly has a buried Btk-Ck or Bwk-Ck horizon sequence. Carbonate accumulations on ped surfaces, in root channels, and as concretions along with dark iron-manganese concretions are the most common pedogenic processes. Pedogenic properties and stratigraphic position correlate to the Arlington paleosol of Ferring (1990).

Aubrey/Carrollton alluvium occurs beneath younger Pilot Point and/or Sanger alluvium in the Dallas Floodway Extension area (Cliff et al. 1998). This unit is characterized as a dark grayish (10YR 5/1) to yellowish brown (10YR 7/6) silty clay loam to clay loam that is interbedded with sandy loam to sand. Plant roots, root traces filled with carbonate and/or iron oxide, carbonate concretions, and gastropod shells characterize the unit. Soil development at the top of the unit is commonly weak, and C or Cg horizons were noted in most samples from this area.

Coppell/Tioga alluvium was identified at a single location beneath the Pleistocene terraces in the Dallas Floodway Extension area (Cliff et al. 1998). At this location, a reddish (5YR 6/8) sandy clay loam Bt horizon with grayish (10YR 7/2) mottles was identified. Paleosol characteristics include moderate development of soil structure, clay accumulations on peds and in root traces, and manganese stains and concretions. The paleosol grades downward into bedded sand and gravel.

The data collected in the Dallas Floodway Extension area, in association with that from previous investigations in the Trinity River valley, were used to develop a general landscape evolution summary of the floodway extension area (Cliff et al. 1998). Geomorphological map units and alluvial deposits within the Dallas Floodway Extension were correlated with Ferring's (1990) model for the purpose of inferring regional events in the Trinity River basin (Table 3). This general landscape evolution summary can be used as a base with which to interpret the new data collected from the Dallas Floodway. A refined landscape evolution summary can, in turn, be used as a model to further infer general paleoenvironmental evolution, assess archeological site distribution data, and provide cultural resources management recommendations for areas to be impacted by future projects. 
Comparison of Upper Trinity River Stratigraphy to Units in the Dallas Floodway Extension Area (after Cliff et al. 1998)

\begin{tabular}{|c|c|c|c|c|}
\hline \multicolumn{3}{|c|}{ Upper Trinity River ${ }^{1}$} & \multicolumn{2}{|c|}{ Dallas Floodway Extension ${ }^{2}$} \\
\hline Alluvium & Terrace Surface & Age & Alluvium & Surface(s) \\
\hline Pilot Point & Denton Creek & $<4,500$ years & Pilot Point & Holocene flood plain (Hf) \\
\hline Sanger & Denton Creek & 4,500 to 11,000 years & Sanger & $\begin{array}{l}\text { Holocene flood plain, } \\
\text { older surfaces (Hfo) }\end{array}$ \\
\hline Aubrey & Denton Creek & $\begin{array}{l}11,000 \text { to } 25,000 ? \\
\text { years }\end{array}$ & Aubrey/Carrollton & $\begin{array}{l}\text { Holocene flood plain, } \\
\text { older surfaces (Hfo) }\end{array}$ \\
\hline Carrollton & Hickory Creek & $\begin{array}{l}>15,000 \text { years } \\
\quad(\text { ca. 25,000 years?) }\end{array}$ & & \\
\hline Coppell/Tioga & Stewart Creek & $>30,000$ years & Coppell/Tioga & Pleistocene terraces (Pt) \\
\hline Irving & Stewart Creek & $>30,000$ years & not identified & \\
\hline
\end{tabular}

${ }^{1}$ Ferring 1990, 1995; Humphrey and Ferring 1994

${ }^{2}$ Cliff et al. 1998

The oldest Trinity River deposits identified in the floodway extension area belong to the Coppell/Tioga alluvium. This unit reflects a period of slow valley alluviation at a base level higher than present. Stream channels were relatively shallow, bedload-dominated meander belts; climatic conditions were probably comparable to the present. The unit formed in middle Wisconsin time, probably before 30,000 years ago (Ferring 1990).

The onset of continental glaciation produced widespread and rapid valley incision throughout much of Central Texas (Blum et al. 1994; Ferring 1990). Climatic instability and associated increases in effective precipitation not only induced incision of the Trinity River into its present flood plain, but also resulted in alluviation of the Aubrey/Carrollton sequence in a low relief, wetland-dominated flood plain. The lithologic and stratigraphic attributes of this unit suggest that the Trinity River flood plain was a mosaic of swamps, marshes, and lakes with interspersed scattered stream channels. Sediment delivered to the flood plain was derived from erosion of the upland residuum, triggered by vegetational instability associated with full glacial climate changes (Blum et al. 1994).

Rapid alluviation in the Trinity River ensued with early Holocene meander belt development and deposition of the Sanger alluvium (Ferring 1990). A return to increased climatic stability and seasonality occurred at that time (Blum et al. 1994). The lithology of the Sanger alluvium may in part be a result of the widespread exposure of Cretaceous bedrock in the Trinity River basin following the Late Pleistocene stripping of residuum. The middle Holocene is characterized by a transition toward modern climatic conditions. The Trinity River flood plain exhibited a slowing of the rate of alluviation and a concurrent increase in the rate of alluvial pedogenesis (Ferring 1990). 
The Late Holocene is typified by varying rates of alluviation and pedogenesis, as well as deposition of channel belt alluvium and overbank veneers draping older flood plain surfaces. Soil formation was concurrent with sedimentation to produce the thick, cumulative West Fork paleosol at the top of the Pilot Point alluvium (Ferring 1990). The most significant disruption in the cumulative aggradation of the Pilot Point sequence is an inferred period of drier climate about 1,000 years ago (Hall 1990). Hall cites widespread occurrence of an alluvial discontinuity in the Southern Great Plains; however, the Dallas Floodway Extension investigations generated no data to either support or refute this idea.

Recent alluviation occurs near the modern channel of the Trinity River. Recent overbank veneers probably drape the entire Trinity River flood plain. In some areas, these recent clayey deposits can be distinguished from the older Pilot Point sediments capped by the West Fork paleosol by a difference in color, level of soil development, or the presence of cultural materials of historic age. In other areas, these mud drapes could not be confidently separated from upper Pilot Point alluvium based on the available data from the Dallas Floodway Extension project. Ferring (1990) indicates that the recent alluvium is young, but he does not specifically correlate this unit to the onset of European settlement in the region. It has been suggested that similar alluviation associated with Euro-American land use alteration occurred throughout the Mississippi River drainage basin (Autin 1992; Bettis and Autin 1997; Grissinger et al. 1982; Knox 1972).

\section{DATA AND OBSERVATIONS}

A series of 10 backhoe trenches was excavated within or directly adjacent to Wetland Cell D (see Figure 2). These trenches were dug to form six short transects spaced approximately $100 \mathrm{~m}$ apart. Four of these transects contained two trenches, and the other two contained only one trench. The trenches located along the western edge of the cell were excavated to a depth of roughly $2 \mathrm{~m}$, but those closer to the center of the cell were excavated to an approximate depth of $3 \mathrm{~m}$ or until conditions made it impractical to dig deeper (BHT 5 encountered water at $2 \mathrm{~m}$ ). In most instances, exact trench locations were dependent on vegetation and terrain. Back dirt from the trenches was examined for artifacts, as were the trench walls. Trench walls were cleaned, and the different zones and their relationship were described. These trench descriptions are given in Appendix A. Two cross sections were then prepared, making use of the current and previous trench data (Figures 7 and 8).

As might be anticipated, the deposits in the trenches along the western side of Wetland Cell D show considerable impact from the construction of I-45 located immediately to the west as well as from the Dallas Central Wastewater Treatment Plant farther to the west (see Figure 7). What is surprising is the depth of the disturbance $(80$ to $140 \mathrm{~cm}$ ) and the fact that there is up to $80 \mathrm{~cm}$ of alluvium resting on top of the disturbed zone indicating that there have been extremely high rates of deposition in this area after the construction of I-45. Further, much of this very recent alluvium is quite sandy, indicating that the water energy at the time of deposition was fairly high. Almost all this alluvium is laced with very recent debris (cellophane, soda cans, metal, plastic, Styrofoam, and decaying wood). As can be seen from Figure 8, this sandy recent deposit is present in most of the trenches in the center of Cell $\mathrm{D}$ as well as in the areas of site 41DL337 to the northwest and sites 41DL318 and 41DL319 to the south and east. This indicates that the 
figure

7. Cross section along the western edge of Cell D 
environment and conditions that produced this deposit were quite widespread. It also indicates that there has been a significant change in conditions on the flood plain, since deposits of this nature would normally be confined to the meander belt of the active river channel, which in the case of the Trinity has historically been quite narrow.

Beneath the sandy-rich, very recent alluvium, the northern two trenches in the center of Cell D (BHTs 2 and 4) both encountered roughly $50 \mathrm{~cm}$ of debris-laden fill that contained plastic, rusting metal, and glass. Given that these two trenches were near the slough-like feature in the northern portion of Cell D, this debris may represent a historic surface dump. South of this area is the site of a filled sludge pit that had been used by the wastewater treatment plant. This pit occupies the southwestern portion of the northern one-third of Cell $\mathrm{D}$, and its approximate limits are marked by the current tree line. BHT 5 was excavated on the northeastern corner of this pit and encountered approximately $1 \mathrm{~m}$ of pit fill beneath 55 to $60 \mathrm{~cm}$ of clay pit seal. Not surprisingly, the pit continues to retain water as evident by the perched water table encountered by BHT 5 . BHTs 6 and 8 , on the other hand, appeared to penetrate deposits that were relatively undisturbed and in situ. BHT 8 encountered dark gray, clay-rich sediments that were extremely calcareous, contained gastropod shell fragments, and exhibited a modest level of soil development. The deposits observed in BHT 6 were even darker, exhibiting a slightly more advanced level of soil development. These sediments are very typical of the Holocene-age, calcareous, clay-rich, fluvial back-swamp deposits found on the Trinity River's flood plain in much of the region. In fact, virtually every trench in Cell D encountered similar clay-rich sediments once the cover of sandy recent alluvium, fill material, and disturbed deposits had been penetrated. This would strongly indicate that this area had been located in a fluvial back-swamp environment during the later part of the Holocene.

To summarize the field observations, the 10 backhoe trenches in Wetland Cell D encountered a layer of sandy recent alluvium of varying thickness that blankets most of the surface. Beneath this layer is often a zone composed of fill or disturbed materials. In some cases, this zone appears to be surface dumps of historic age now buried by more recent flood deposits, but in other areas this zone appears to be the result of highway construction connected with I-45 or the operation of the nearby Dallas Central Wastewater Treatment Plant. Underlying this zone are calcareous, clay-rich sediments that are likely of Holocene age and represent deposition in a fluvial back-swamp environment.

\section{DISCUSSION AND INTEGRATION WITH PREVIOUS WORK}

Wetland Cell D is located near the center of an area that has undergone a series of geomorphological studies very recently. During studies done for the Dallas Floodway Extension Project, Autin excavated and examined four trackhoe trenches just to the northwest of Cell D and recorded six Geoprobe ${ }^{\circledR}$ profiles on portions of the surrounding flood plain (Figure 9; Cliff et al. 1998). The EC traces recorded by the Geoprobe ${ }^{\circledR}$ were re-interpreted in light of the results of the current project (see Appendix B). Considerable additional work was done during the testing of sites 41DL337, 41DL338, 41DL355, and 41DL356 to the northwest of Cell D directly north of the Dallas Central Wastewater Treatment Plant and sites 41DL318 and 41DL319/357 to the southeast of Cell D. Forty trackhoe trenches were excavated and examined as well as a considerable number of test units (Buysse 2000). Figure 8 shows the relationship of the sediments encountered in Cell D to those observed during the work done by Buysse and Cliff et al. 
figure

8. Cross section showing relationship of Cell D deposits to those at site 41DL337 to the northwest and sites 41DL318 and 41DL319/357 to the southeast 
Geoarcheological Investigations of Wetland Cell D within the Dallas Floodway Extension Project Area, Dallas, Texas

\section{figure 8}


figure

9. Relationship of the Wetland Cell D project to previous investigations of the geomorphology of the Dallas Floodway Extension project area

(from Cliff et al. 1998) 
Geoarcheological Investigations of Wetland Cell D within the Dallas Floodway Extension Project Area, Dallas, Texas

\section{figure 9}


As can be seen from Figure 8, all of the trenches penetrated late Holocene deposits belonging to the Pilot Point alluvium. The data from Cell D and surrounding areas, however, make two other facts very clear. First, the near-surface deposits have been heavily disturbed if not completely removed over a considerable portion of this area. As noted above, approximately the upper $1 \mathrm{~m}$ of deposits in Cell D has been disturbed or replaced with fill material. BHT 5 encountered the edge of a filled sludge pit where it appears that approximately $1.5 \mathrm{~m}$ of preexisting deposits were removed. A number of trenches in the areas surrounding Cell D also encountered filled sludge pits, some of which exceed $3 \mathrm{~m}$ in depth (Buysse 2000; Cliff et al. 1998). In other areas such as the southern portion of site 41DL319/357, significant amounts of the near-surface deposits have been removed by borrow pit activities. Although few areas of the Trinity River flood plain have been examined as intensely as the area of Cell D to allow for a meaningful comparison, it seems likely that the level of near-surface disturbance is unusually high. This would seem logical given the proximity of the wastewater treatment plant with its associated levees and numerous sludge pits and settling ponds as well as the I-45 bridges and historic trash dumps (site 41DL320). Another less obvious impact of modern activities in this area is the blanket of sandy alluvium that covers virtually the entire area. Near the current channel of the Trinity River these very recent, sand-rich deposits may be 1 to $1.5 \mathrm{~m}$ in thickness (Cliff et al. 1998), which would be expected for natural levee deposits in the river's active meander belt. What is unusual is that these deposits are often 60 to $80 \mathrm{~cm}$ thick more than $200 \mathrm{~m}$ from the edge of the active channel. As noted before, this would imply that the energy of the flow regime over much of this portion of the flood plain during flood events is much higher now than it was in the past or would be anticipated based on its location relative to the river's meander belt. This increased energy is likely due to the fact that this area is just downstream of the end of the current Trinity River levee where the river was channelized in the 1930s. As a consequence, the floodwaters reaching the end of this narrow, constricted portion of the Trinity River's flood plain have much more energy and are carrying coarser clastic material than was the case historically. Although the deposition of new alluvium presents no threat to existing deposits, the high energy floodwaters are just as likely to cause increased erosion and scouring of preexisting sediments along the margins of the existing channel and in lower portions of the flood plain. Buysse (2000:73) noted a measurable amount $(30 \mathrm{~cm})$ of cutbank erosion at site 41DL319/357 in just a few months. Other areas may be suffering erosion of similar or even greater nature. In several areas within Cell $\mathrm{D}$, there is no vegetation on the surface, a lack of any in situ organic debris such as leaf litter, and the presence of thick piles of water-transported modern trash (cans, bottles, Styrofoam, and the like) on the surface, as well as logs, branches, and grass draped on the upstream side of tree trunks - abundant evidence that these areas have been repeatedly swept by floodwaters.

The second thing that is clear from the data in this area is that the mid- to late-Holocene-age alluvium (the "Pilot Point alluvium" of Ferring and others) is extremely variable in thickness. In Cell D, it is over $3 \mathrm{~m}$ thick everywhere. At site 41DL337 to the northwest, it is at least $3.5 \mathrm{~m}$ thick. Geoprobe ${ }^{\circledR}$ data between these two locations indicate a thickness of 3.5 to $4 \mathrm{~m}$ (Cliff et al. 1998, Probes 15, 16, and 17; see Appendix B). Probe 5 located to the northeast of Cell D (see Figure 9) appears to have penetrated $4.28 \mathrm{~m}$ of Pilot Point resting directly on the Cretaceous Austin Chalk. To the southeast, trenches excavated at sites 41DL318 and 41DL319 consistently revealed 3.5 to $4.2 \mathrm{~m}$ of deposits from the mid-Holocene or later (Buysse 2000). The results from Probe 4 located to the east-northeast of these sites and adjacent to the current Trinity River channel (see Figure 9) indicate that the Pilot Point can be over $9.7 \mathrm{~m}$ thick in this area. Probe 7 located due south of Probe 4 and closer to the valley margin (see Figure 9) indicates that the thickness of the Pilot Point can decrease rapidly in very short distances. This same phenomenon 
was noted in areas farther upstream where the Pilot Point alluvium varied from a few meters to nearly $10 \mathrm{~m}$ in thickness (Cliff et al. 1999). This variation seems to be dependent on the area's distance from the valley margin and on the area's location in relation to the present and past channels of the Trinity River.

Although there is a considerable variation in the thickness observed, the nature of the Pilot Pointage sediments is fairly uniform and monotonous. With the exception of the silty, sandy deposits of very recent age, the post-mid-Holocene sediments are consistently calcareous, gray to dark gray in color, and clay-rich with minor amounts of sand and silt. They often contain gastropod shell fragments, minor amounts of decaying organic matter (generally grass and small roots), and very small rounded pebbles. The fine-grained nature of these sediments would strongly suggest that they were deposited in a fluvial back-swamp environment. This view is supported by radiocarbon dates derived from soil humates from BHT 16 at site 41DL319 and from Unit 6 at site 41DL356 that indicate average sedimentation rates of roughly 0.6 to $0.9 \mathrm{~mm}$ per year; this reflects the low rates of sediment accumulation anticipated in this type of environment. The only exceptions in this area are some sandy, silty deposits encountered in trenches at site 41DL319/357. Given the location of these trenches directly adjacent to the current Trinity River channel, it is likely that these deposits are part of the sandy natural levee that often forms adjacent to the river channel in an active fluvial meander belt.

The most important feature of the Pilot Point in this area, however, is that it appears to date from several distinctly different time periods within the Holocene. As noted previously, the Pilot Point is not a true time-stratigraphic unit and has actually accumulated at differing rates and times in different areas. In examining Figures 7 and 8, it seems clear that the Pilot Point in Cell $\mathrm{D}$ and the areas surrounding it can be divided into deposits dating from the mid-Holocene, those dating to historic times, and those deposited in the very recent past. The very recent sand-rich deposits have already been discussed above. They must date to the period after 1932 and in all likelihood are much more recent than that based on the types of debris found embedded in them. These sand-rich sediments form a veneer over much of the area and rest unconformably on the underlying deposits. The next unit below the present surface are the clay-rich portions of the Pilot Point that appear to be of historic age. This unit often contains rusting metal and other artifacts that date to the period after the Euro-American settlement of this area. This zone is highly variable in thickness being at least $3 \mathrm{~m}$ thick in parts of Cell D, 0.65 to $2 \mathrm{~m}$ thick at sites 41DL318 and 41DL319 to the southeast, and $0.5 \mathrm{~m}$ thick to completely absent at site 41DL337 to the northwest (see Figure 8). In many areas, the upper portion of this unit displays some organic enrichment and a modest level of soil development. This would indicate either that the top of this zone was a somewhat stable surface or that the rate of sediment accumulation had slowed enough to allow for increased organic input. Despite the generally fine-grained nature of the deposits, however, the rate of sedimentation must have been fairly high. Assuming that these deposits began accumulating approximately 200 years ago, average sedimentation rates in Cell D would be 13 to $15 \mathrm{~mm}$ per year (BHTs 6 and 8). This is approximately 4 to 5 times the normal rate for accumulation in a fluvial back-swamp environment and 15 to 20 times the sedimentation rates calculated for the underlying portions of the Pilot Point noted above. The contact between this historic-age unit and the underlying portion of the Pilot Point appears to be erosional, based on the abruptness of the boundary between them in some areas and the sharp topographic variation this surface displays over short lateral distances (see Figure 8, sites 41DL318 and 41DL319). 
The reason for this increased rate of deposition and the erosional removal of some portion of the underlying sediments seem to be two-fold. First, it is likely that human activities during historic times - such as land clearing, agricultural and grazing activities on the uplands, and increased water discharge onto the flood plain during storms-led to increased soil erosion on the uplands and redeposition on the flood plain. This increased influx of material to the Trinity flood plain may have peaked fairly early and then begun to decrease as increased population densities led to a reduction in agricultural land use and a "hardening" of the upland land surface as increasing amounts of this surface were paved over or put back into constant vegetation (parks and lawns). This reduction in sediment supply may account for the increased amount of organic material and modest soil development noted in the upper portion of these deposits. Second, given the effective width of the post mid-Holocene flood plain in this area (approximately $700 \mathrm{~m}$ between the preserved pre-mid-Holocene fluvial terraces on both sides of the Trinity River's valley), the Trinity River would have been confined to a very narrow belt over the past several thousand years. Geoprobe ${ }^{\circledR}$ data from this area (Cliff et al. 1998) and from studies upstream to the west (Cliff et al. 1999) make it clear that the active channel of the Trinity River has incised as much as 8 to $11 \mathrm{~m}$ into its flood plain in the later half of the Holocene. That is, the thickness of the Pilot Point alluvium deposited within the Trinity River's meander belt is on the order of $10 \mathrm{~m}$. In examining the data from Probe 5 to the northeast, Probe 7 to the southeast, and Probes 15, 16, and 17 to the northwest of Cell D (see Figures 2 and 9), it is noted that there are approximately 3 to $5 \mathrm{~m}$ of Pilot Point alluvium at each of these locations. This is significantly less than would be expected if these areas had been within the Trinity River's meander belt at some point in the later part of the Holocene. This means that the actual width of the flood plain may be more on the order of $500 \mathrm{~m}$ and possibly less. With the river confined within a fairly limited area coupled with a sudden increase in the sediment supply, it seems reasonable to suppose that the Trinity River would have eroded deeply into the preexisting sediments in this portion of its valley and replaced them with younger materials. Figure 8 seems to indicate that Cell D was within the area that was swept clean of much of the earlier deposits. This axis of erosion followed by historic sedimentation passes through Probe 4 just northeast of site 41DL319/357 (see Figure 9).

Underlying these historic-age deposits are mid- to late-Holocene fluvial deposits that are capped by the West Fork paleosol. The depth to the top of this zone is highly variable, being as little as $60 \mathrm{~cm}$ in portions of site 41DL337 to $2.8 \mathrm{~m}$ in the north of Cell D. In some areas, it appears that it has been completely removed (near Probe 4 for example). It seems likely that fluvial activity has also eroded it severely over much of Cell D. Where it is preserved, the data strongly indicate that this part of the Pilot Point was deposited in a fluvial back swamp where the average rate of deposition was extremely low. Radiocarbon dates from soil humates collected in this area indicate that this unit was accumulating between approximately 3,050 and 1,330 years B.P. (Buysse 2000; Cliff et al. 1998). Nonetheless, radiocarbon dates derived from charcoal and ash associated with prehistoric cultural materials yielded dates of 480 and 1,000 years B.P. near the upper surface of the West Fork, 970 years B.P. roughly $60 \mathrm{~cm}$ below the top of the West Fork, and 2,140 years B.P. approximately $1.7 \mathrm{~m}$ below the current top of the West Fork (Buysse 2000:Table 54). This would seem to indicate that the radiocarbon dates from soil humate overestimate the age of the West Fork paleosol, at least in this area. This overestimation of the West Fork's age may be due to the inclusion of older organic material in the West Fork paleosol. That is, sediment that formed the West Fork may have already contained some organic material from earlier periods. This would seem quite reasonable given that the Pilot Point alluvium was going to contain organically enriched sediment that was being eroded off the surrounding 
uplands and redeposited on the flood plain as well as material derived from the erosion of older flood plain deposits. Nevertheless, all these dates show that the West Fork paleosol formed in the last few thousand years of the Holocene and that in many areas it formed a stable surface by roughly 1,000 years B.P. By extension, the underlying portion of the Pilot Point alluvium must date mainly to the mid- to late-Holocene. The West Fork surface has now been modified by later erosion that has removed some of the paleosol's over-thickened, cumulic "A" soil horizon. Further, it is clear that there is a considerable time gap between the termination of West Fork paleosol sedimentation and the onset of the deposition of the overlying historic and very recent sediments.

The Pilot Point alluvium, in turn, rests upon a variety of preexisting deposits. In some areas, the Pilot Point rests directly on the eroded Cretaceous surface. In others, it forms a veneer of varying thickness above older fluvial sediments of the Sanger, Aubrey/Carrollton, and Coppell/Tioga alluvia. As might be anticipated, near the margins of the Trinity River's valley including the higher fluvial terraces adjacent to the study area, the Pilot Point is less than $3 \mathrm{~m}$ thick and is completely absent in some locations. In the large fluvial terrace southwest of Cell D, the Pilot Point appears to be underlain by portions of the early to middle Holocene-age Sanger alluvium. In some instances, the Sanger in turn rests on terminal Pleistocene deposits while in others it rests directly on the Cretaceous Austin Chalk. The Quaternary deposits are up to $10.5 \mathrm{~m}$ in thickness in this area, indicating the Trinity River's channel was once considerably farther to the south or perhaps that some of the small tributaries in this area were once larger and capable of carving out significant side valleys. On the opposite side of the valley, the low fluvial terrace northwest of Probe 6 also appears to be composed principally of Sanger alluvium. However, in Probe 6 (located near the edge of the active Trinity River flood plain; see Figure 9), late Pleistocene deposits of the Coppell/Tioga alluvium were discovered beneath the Pilot Point, indicating that the adjoining high fluvial terrace composed of Pleistocene sediments once extended farther to the south. Farther to the south and directly east of Cell D, Probe 5 (see Figure 9) encountered Austin Chalk at a depth of approximately $4.3 \mathrm{~m}$ indicating that there is considerable topography hidden beneath the current flood plain surface. Northwest of Cell D, Probes 15, 16, and 17 all encountered Sanger alluvium underneath the Pilot Point. In one case, the Sanger rested directly on the Austin Chalk at a depth of $11.5 \mathrm{~m}$ while in another the Sanger rested on terminal Pleistocene sediments. This pattern of a complex quilt of differing age deposits of varying thickness hidden beneath relatively smooth surfaces that give no indication of the underlying complexity is very typical of the Trinity River valley (see Cliff et al. 1999). Thus, it is unclear what sediments may lie beneath the Pilot Point in Cell D. What is clear is that within Wetland Cell D, there are no pre-middle Holocene sedimentary deposits at a depth of less than $3 \mathrm{~m}$.

\section{SUMMARY AND ARCHEOLOGICAL IMPLICATIONS}

Ten backhoe trenches were excavated within the approximate limits of Wetland Cell D. From the data gathered from these trenches and other studies done in the surrounding areas, it appears that the upper $3 \mathrm{~m}$ of sedimentary deposits in Cell D are of very late Holocene age that probably dates to after the Euro-American settlement of this region. The upper portion of these deposits has been extensively disturbed over most of Cell D by the construction of I-45 and the operations connected with of the Dallas Central Wastewater Treatment Plant farther to the west. The 
disturbed deposits are often capped with sand-rich sediments that contain abundant modern debris. Only one trench encountered the West Fork paleosol that is so ubiquitous in the areas surrounding Cell D. In fact, the data suggest that Cell D is located along or near the axis of a recent Trinity River meander belt that has cut deeply into the preexisting Quaternary sediments. This channel cut was then rapidly filled with fine-grained deposits possibly derived from the surrounding uplands and other areas upstream.

The geologic history of this area has important implications for the potential for buried, sealed cultural deposits. First, significant amounts of prehistoric cultural material exist in the late Holocene sediments to the northwest and southeast of Cell D. All of this material, however, was found within or directly on top of the surface of the West Fork paleosol. Since it is almost certain that the West Fork has been significantly eroded, if not entirely removed, over most of Cell D and replaced by younger sediments, it seems very unlikely that prehistoric cultural sites dating to the late Holocene have remained intact.

Next, it is possible that sediments dating to earlier portions of the Holocene or even the terminal Pleistocene are located within Cell D based on their presence in adjoining areas. It is equally likely, however, that they too have either been deeply eroded or swept away by later fluvial activity. Even if they were present, they would be at a depth greater than $3 \mathrm{~m}$ and locating them would be extremely difficult. Determining areas in or on these buried sediments that would be favorable for the preservation of cultural materials would be virtually impossible given the depth of burial and the patchwork nature of the deposits involved.

Lastly, there are at least two factors that have operated to make Cell D a relatively unique location in the proposed Dallas Floodway Extension project and greatly limit its potential for buried cultural sites. First, as noted above, approximately the upper $1 \mathrm{~m}$ of sediments in Cell D has been extensively disturbed. Given Cell D's location, it seems likely that the intensity and pervasiveness of disturbance may be unique to this area. Second, the confined nature of the Trinity River's flood plain in this area in the later portion of the Holocene with the consequent restriction in the movement of the river's meander belt appears to be a highly unusual situation. It is this confinement that probably led to the erosion of the West Fork paleosol and older portions of the Pilot Point within Cell D. Because of these two unusual circumstances, it would be very difficult to extrapolate the geologic and geomorphologic situation in this area to other areas within the proposed Dallas Floodway Extension project. 
Geoarcheological Investigations of Wetland Cell D within the Dallas Floodway Extension Project Area, Dallas, Texas 


\section{CHAPTER 5 RECOMMENDATIONS}

The examination of the profiles of the 10 trenches (see Appendix A) revealed significant disturbance throughout much of the area, particularly the upper meter of the deposits. The presence of a former sludge pit related to the Dallas Central Wastewater Treatment Plant was also discovered in the area of BHTs 5 and 6. In a number of trenches, a buried A horizon potentially equivalent to the West Fork paleosol was noted; nevertheless, these buried A horizons were not as distinct as the A horizon previously documented to the south at the locations of sites 41DL318 and 41DL319/357. More important, however, was the total lack of any evidence of prehistoric occupation in association with any of these buried A horizons.

The backhoe investigations revealed that the proposed area of Wetland Cell $\mathrm{D}$ has been previously disturbed by activities related to the wastewater treatment plant sludge pit, the deposition of fill deposits, and flooding action. The backhoe investigations did reveal buried A horizons, but no prehistoric occupation surfaces were encountered. It is considered unlikely that this particular locality is typical of the greater Dallas Floodway project area; nonetheless, previous investigations (Cliff et al. 1998) have indicated that various areas of the Trinity River flood plain have been previously disturbed by a growing city. It is recommended that the construction of the proposed Wetland Cell D will have no effect upon historic properties. Given the particulars of the geological setting of Wetland Cell D and the large-scale historic disturbances found in this area (especially I-45 and the Dallas Central Wastewater Treatment Plant), the results of this investigation cannot be extrapolated beyond Wetland Cell D; the other proposed wetland cells will need to be evaluated in a similar manner in order to properly assess whether or not archeological deposits with contextual integrity are present. 
Geoarcheological Investigations of Wetland Cell D within the Dallas Floodway Extension Project Area, Dallas, Texas 


\section{REFERENCES CITED}

Adovasio, J. M.

1992 Summary of Results of Archaeological Monitoring of Bridge Pier Construction Activities Associated with the DART South Oak Cliff Light Rail Project, Line Section OC-2-Trinity River Aerial Structure. Archaeology Research Program, Southern Methodist University, Dallas. Submitted to Huitt-Zollars, Inc., Dallas. Reproduced in Archaeological Investigations of the South Oak Cliff Line and DART Cultural Resources Management, vol. II, by S. A. Skinner, B. B. Whorton, L. K. Trask, R. Scott, S. C. Caran, and J. S. Dillon. AR Consultants, Dallas. Submitted to Dallas Area Rapid Transit, Dallas.

Allen, P. M., and W. D. Flanigan

1986 Geology of Dallas, Texas, United States of America. Bulletin of the Association of Engineering Geologists 23(4):363-418.

Antevs, E.

1955 Geological Climatic Dating in the West. American Antiquity 20(4):317-335.

Anthony, D., and D. O. Brown

1994 Archeological Investigations in the Denton Creek Floodplain: Data Recovery Excavations at 41DL270, Denton and Dallas Counties, Texas. Texas Antiquities Permit No. 1176. Archeology Series 37. Hicks \& Company, Austin.

Archaeology Research Program (ARP)

1982 Settlement of the Prairie Margin: Archaeology of the Richland Creek Reservoir, Navarro, and Freestone Counties, Texas, 1980-1981, A Research Synopsis. Archaeological Monographs, Number 1. Archaeology Research Program, Southern Methodist University, Dallas.

1989 South Oak Cliff Line. Archaeology Research Program, Southern Methodist University, Dallas. Submitted to Parsons Brinckerhoff, Inc., Dallas, Task No. 104. 
1991 Trinity River Floodplain Monitoring Results. Archaeology Research Program, Southern Methodist University, Dallas. Cited in Appendix A, Archaeological Investigations of the South Oak Cliff Line and DART Cultural Resources Management, vol. I, by S. A. Skinner, B. B. Whorton, L. K. Trask, R. Scott, S. C. Caran, and J. S. Dillon. AR Consultants, Dallas. Submitted to Dallas Area Rapid Transit, Dallas.

Austin, S. P.

1993a A Cultural Resource Survey of the Proposed Impact Areas, Duck Creek Channel Improvement, Garland, Dallas County, Texas. Report of Investigations 93-01. Stephen P. Austin, Consulting Archeologist.

1993b A Cultural Resource Investigation of the Proposed Impact Areas at the Penn Farmstead (41DL192), Cedar Hill, Dallas County, Texas. Miscellaneous Reports of Investigations No. 61. Geo-Marine, Inc., Plano, Texas.

Autin, W. J.

1992 Use of Alloformations for Definition of Holocene Meander Belts in the Middle Amite River, Southeastern Louisiana. Geological Society of America Bulletin 104:233-41.

Baker, K.

1988 Industrial Properties Corporation-Our 60 Years: 1928-1988. Industrial Properties Corporation, Dallas.

Bell, R. E.

1984 Protohistoric Wichita. In Prehistory of Oklahoma, edited by R. E. Bell, pp. 363378. Academic Press, New York.

Bell, R. E., and T. Bastian

1967 Preliminary Report Upon Excavations at the Longest Site, Oklahoma. In A Pilot Study of Wichita Indian Archaeology and Ethnohistory, assembled by R. E. Bell, E. B. Jelks, and W. W. Newcomb, pp. 119-127. Submitted to the National Science Foundation.

Bell, R. E., E. B. Jelks, and W. W. Newcomb (assemblers)

1967 A Pilot Study of Wichita Indian Archaeology and Ethnohistory. Submitted to the National Science Foundation.

Bennett, J., S. A. Skinner, S. Judd, J. Kaskey, J. Raley, and D. Shanabrook

1981 Cultural Resources Survey of the Dallas Floodway Extension. Cultural Resources Program Investigative Report 81-26. Environment Consultants, Inc., Dallas.

Bettis, E. A., III, and W. J. Autin

1997 Complex Response of a Midwestern, USA Drainage System to Late Wisconsinan Sedimentation. Journal of Sedimentary Research 67:740-748. 
Blair, W. F.

1950 The Biotic Provinces of Texas. Texas Journal of Science 2(1):93-117.

Blum, M. D., R. S. Toomey III, and S. Valastro, Jr.

1994 Fluvial Response to Late Quaternary Climatic and Environmental Change, Edwards Plateau, Texas. Palaeogeography, Palaeoclimatology, Palaeoecology 108:1-21.

Bousman, B., and L. Verrett

1973 An Archaeological Reconnaissance of Aubrey Reservoir. Report No. 18. Archaeology Research Program, Southern Methodist University, Dallas.

Boyd, D. K., and S. A. Tomka

1990 Summary and Recommendations. In Phase II Investigations at Prehistoric and Rock Art Sites, Justiceburg Reservoir, Garza and Kent Counties, Texas. 3 vols. By D. K. Boyd, J. T. Abbott, W. A. Bryan, C. M. Garvey, S. A. Tomka, and R. C. Fields, pp. 1:235-1:273. Report of Investigations Number 71. Prewitt and Associates, Inc., Austin.

Brown, D. O., R. P. Watson, D. Peter, and R. Rawn-Schatzinger

1987 McDonald Site-41HI105 (X41HI171). In Archeology at Aquilla Lake: 1978-1982 Investigations, vol. 1, compiled by D. O. Brown, pp. 38-1 to 38-145. Research Report No. 81. Texas Archeological Survey, University of Texas at Austin.

Brown, $\mathrm{H}$.

1988 A Preliminary Assessment of Cultural Resources in the Marine and Tony's Creek Area, Fort Worth, Tarrant County, Texas. Institute of Applied Sciences, North Texas State University, Denton. Submitted to U.S. Army Corps of Engineers, Fort Worth District, under Contract No. DACW63-85-D-0066. Copies available from U.S. Army Corps of Engineers, Fort Worth District.

Brown, K. L., and S. A. Lebo

1991 Archaeological Testing of the Lewisville Lake Shoreline, Denton County, Texas. Institute of Applied Sciences, University of North Texas, Denton.

Bruseth, J. E., and N. A. Kenmotsu

1991 Soldiers of Misfortune: The de Soto Expedition Through Texas. Heritage 9(4):1217.

Bruseth, J. E., and W. A. Martin

1987 The Wylie Focus: Cultural Reality or Archaeological Myth. In The Bird Point Island and Adams Ranch Sites: Methodological and Theoretical Contributions to North Central Texas Archaeology, edited by J. E. Bruseth and W. A. Martin, pp. 267-284. Richland Creek Technical Series, vol. II. Archaeology Research Program, Southern Methodist University, Dallas. 
Bruseth, J. E., and W. A. Martin (editors)

1987 The Bird Point Island and Adams Ranch Sites: Methodological and Theoretical Contributions to North Central Texas Archaeology. Richland Creek Technical Series, vol. II. Archaeology Research Program, Southern Methodist University, Dallas.

Bruseth, J. E., and R. W. Moir (editors)

1987 Introduction to the Richland Creek Archaeological Project: Environmental Background and Cultural Setting. Richland Creek Technical Series, vol. I. Archaeology Research Program, Southern Methodist University, Dallas.

Bureau of Economic Geology

1972 Geologic Atlas of Texas. Dallas Sheet. Bureau of Economic Geology, The University of Texas at Austin.

Burson, E.

2000a Cultural Resources Survey of the Proposed West Fork Relief Interceptor WF-G, Dallas County, Texas. Miscellaneous Reports of Investigations No. 198. GeoMarine, Inc., Plano, Texas.

2000b Cultural Resources Survey of the Proposed Channel Improvement Along Little Fossil Creek, Haltom City, Tarrant County, Texas. Miscellaneous Reports of Investigations No. 207. Geo-Marine, Inc., Plano, Texas.

Burson, E., and M. B. Cliff

1999 Cultural Resources Survey of the Proposed Environmental Restoration Areas along the Old West Fork of the Trinity River, Dallas County, Texas. Miscellaneous Reports of Investigations No. 196. Geo-Marine, Inc., Plano, Texas.

Burson, E., S. M. Hunt, D. E. Peter, and D. Shanabrook

2000a Cultural Resources Survey of the Proposed West Fork Relief Interceptor WF-11B, Tarrant and Dallas Counties, Texas. Miscellaneous Reports of Investigations No. 190. Geo-Marine, Inc., Plano, Texas.

2000b Cultural Resources Survey of the Proposed West Fork Relief Interceptor WF-11B, Original and Alternate Routes, Tarrant and Dallas Counties, Texas. Miscellaneous Reports of Investigations No. 213. Geo-Marine, Inc., Plano, Texas.

Burton, S. S., and D. T. Connors

1979 An Archaeological Evaluation of Chambers, Richland, and Tehuacana Creeks, Navarro and Freestone Counties, Texas. Archaeology Resource Consultants, Dallas.

Buysse, J. L. (with contributions by W. Autin, M. B. Cliff, R. W. Fullington, S. M. Hunt, W. L. McClure, D. E. Peter, M. Prior, L. Schneibs, D. Shanabrook, and A. Tiné)

2000 An Evaluation of Sites within the Proposed Dallas Floodway Extension Project, Dallas County, Texas. Miscellaneous Reports of Investigations No. 195. GeoMarine, Inc., Plano, Texas. 
Chamberlin, C. (editor)

1972 Environmental and Cultural Impact: Proposed Tennessee Colony Reservoir. 5 vols. Stephen F. Austin State University, Nacogdoches, Texas.

Chipman, D. E.

1992 Spanish Texas 1519-1821. University of Texas Press, Austin.

Cliff, M. B., S. M. Hunt, and D. E. Peter

1989 Cultural Resources Survey of the Weary Site Along Spring Creek, Dallas County, Texas. Miscellaneous Reports of Investigations No. 10. Geo-Marine, Inc., Plano, Texas.

Cliff, M. B., S. M. Hunt, M. Prior, S. Gaither, and W. Autin

1998 Archeological, Architectural, and Geoarcheological Investigations of the Proposed Dallas Floodway Extension Project, Dallas County, Texas. Miscellaneous Reports of Investigations No. 152. Geo-Marine, Inc., Plano, Texas.

Cliff, M. B., D. E. Peter, S. M. Hunt, D. Shanabrook, T. Carter, and V. Green

1996 Archeological Evaluation of the Harbor Pointe Site (41DL369), Dallas County, Texas. Miscellaneous Reports of Investigations No. 120. Geo-Marine, Inc., Plano, Texas.

Cliff, M. B., D. Shanabrook, S. M. Hunt, W. Autin, and M. Prior

1999 Buried Archeological Site Potential in the Dallas Floodway Project Area. Miscellaneous Reports of Investigations No. 187. Geo-Marine, Inc., Plano, Texas.

Crook, W. W., Jr., and R. K. Harris

1952 Trinity Aspect of the Archaic Horizon: Carrollton and Elam Foci. Bulletin of the Texas Archeological Society 23:7-38.

1954 Traits of the Trinity Aspect Archaic: Carrollton and Elam Foci. The Record 12(1):2-16.

1957 Hearths and Artifacts of Early Man near Lewisville, Texas, and Associated Faunal Material. Bulletin of the Texas Archeological Society 28:7-79.

1958 A Pleistocene Campsite near Lewisville, Texas. American Antiquity 23:233-246.

1961 Significance of a New Radiocarbon Date from the Lewisville Site. Bulletin of the Texas Archeological Society 32:327-330.

Dawson, C. L., and T. L. Sullivan

1973 Excavations at Lake Lavon: 1969. Report No. 25. Archaeology Research Program, Southern Methodist University, Dallas.

Dooley, K.

1988 Hidden Dallas. Taylor Publishing Company, Dallas. 
Dorward, D., D. H. Jurney, and G. M. Weston (with contributions by J. McElhaney)

1990 Archaeological Resources Impact Potential of West Oak Cliff Line, Dallas, Texas. Archaeology Research Program, Southern Methodist University, Dallas. Submitted to Parsons Brinckerhoff, Inc., Dallas, Task 90-1. Reproduced in Archaeological Investigations of the South Oak Cliff Line and DART Cultural Resources Management, vol. II, by S. A. Skinner, B. B. Whorton, L. K. Trask, R. Scott, S. C. Caran, and J. S. Dillon. AR Consultants, Dallas. Submitted to Dallas Area Rapid Transit, Dallas.

Dorward, D., and G. M. Weston (with contributions by D. H. Jurney, S. Linder-Linsley, J. McElhaney, R. Moir, and D. Payton)

1990 Archaeological Resources Impact Potential of South Oak Cliff Alternatives, Dallas, Texas. Archaeology Research Program, Southern Methodist University, Dallas. Submitted to Parsons Brinckerhoff Centec, Inc./DeLeuw, Cather \& Company (PBDC), Dallas, Task No. 90-01.

Duffield, L. F., and E. B. Jelks

1961 The Pearson Site, A Historic Site in Iron Bridge Reservoir, Rains County, Texas. Archeology Series 14. Department of Anthropology, University of Texas, Austin.

Edwards, S. K.

1991 Archeological Survey of the Proposed Forest Park Parking Lot Alternative, Fort Worth, Texas. Miscellaneous Reports of Investigations No. 22. Geo-Marine, Inc., Plano, Texas.

Edwards, S. K., and D. E. Peter (with contributions by D. C. Shanabrook, B. C. Yates, and M. B. Cliff)

1991 Archeological Assessment of the Potential Impacts of the Forest Park Parking Lot Alternative on Site 41TR119, Fort Worth, Texas. Miscellaneous Reports of Investigations No. 27. Geo-Marine, Inc., Plano, Texas.

Ferring, C. R.

1989 The Aubrey Clovis Site: A Paleoindian Locality in the Upper Trinity River Basin, Texas. Current Research in the Pleistocene 6:9-11.

1990 Late Quaternary Geology and Geoarchaeology of the Upper Trinity River Drainage Basin, Texas. Field Trip No. 11 Guidebook. 1990 Annual Meeting of the Geological Society of America. Dallas Geological Society, Dallas.

1995 Middle Holocene Environments, Geology, and Archaeology in the Southern Plains. In Archaeological Geology of the Archaic Period in North America, edited by E. A. Bettis, pp. 21-35. Special Paper 297. Geological Society of America, Boulder, Colorado.

2001 The Archaeology and Paleoecology of the Aubrey Clovis Site (41DN479), Denton County, Texas. Center for Environmental Archaeology, Department of Geography, University of North Texas, Denton. 
Ferring, C. R., and N. Reese

1980 Archaeological Investigations at Four Historical Sites within the Lakeview Reservoir Area, Dallas County, Texas. Institute of Applied Sciences, North Texas State University, Denton. Submitted to the U.S. Army Corps of Engineers, Fort Worth District.

Ferring, C. R., and B. C. Yates (with contributions by H. Gill-King and K. Brown)

1997 Holocene Geoarcheology and Prehistory of the Ray Roberts Lake Area, North Central Texas. Institute of Applied Sciences, University of North Texas, Denton.

Ferring, C. R., and B. C. Yates (with contributions by K. L. Brown and M. E. Brown)

1998 Archaeological Investigations at Five Prehistoric Sites at Lewsiville Lake, Denton County, Texas. Center for Environmental Archaeology, Institute of Applied Sciences, University of North Texas, Denton.

Fox, D. E.

1983 Traces of Texas History: Archeological Evidence of the Past 450 Years. Corona Publishing Company, San Antonio.

Fritz, G. C.

1993 Archeobotanical Evidence from the Cobb-Pool Site, A Late Prehistoric Farmstead in Dallas County, Texas. Bulletin of the Texas Archeological Society 64:227-246.

Green, M. M., and F. M. James

1996 Archeological Survey of the Northeast Corridor, Dallas Area Rapid Transit Light Rail System, Dallas County, Texas. Miscellaneous Reports of Investigations No. 137. Geo-Marine, Inc., Plano, Texas.

Green, M. M., F. M. James, and S. M. Hunt

1997 Archeological Survey of the North Central Corridor, Dallas Area Rapid Transit Light Rail System, Dallas and Collin Counties, Texas. Miscellaneous Reports of Investigations No. 135. Geo-Marine, Inc., Plano, Texas.

Grissinger, E. H., J. B. Murphey, and W. C. Little

1982 Late-Quaternary Valley-Fill Deposits in North-Central Mississippi. Southeastern Geology 23(3):147-161.

Hall, S. A.

1990 Channel Trenching and Climatic Change in the Southern U. S. Great Plains. Geology 18:342-45.

Hanson, J. R., and K. K. Kvernes

1997 Upper Trinity Prehistory: Subsistence, Settlement and Chronology as Viewed from the Fountain Site (41TR136). Paper presented at the annual meeting of the Texas Archeological Society, Odessa. 
Harris, R. K., and I. M. Harris

1970 A Bison Kill on Dixon's Branch, Site 27A2-5, Dallas County, Texas. The Record 27(1):1-2.

Harris, R. K., and D. A. Suhm

1963 An Appraisal of the Archaeological Resources of Forney Reservoir, Collin, Dallas, Kaufman, and Rockwall Counties, Texas. Texas Archeological Salvage Project, University of Texas, Austin. Submitted to the National Park Service.

Hays, J. S.

1989 Historic Tribal Groups in the Southern Great Plains. In From Clovis to Comanchero: Archeological Overview of the Southern Great Plains, by J. L. Hofman, R. L. Brooks, J. S. Hays, D. W. Owsley, R. L. Jantz, M. K. Marks, and M. H. Manhein, pp. 247-262. Research Series No. 35. Arkansas Archeological Survey, Fayetteville.

Herz, N.

1990 Stable Isotope Geochemistry Applied to Archaeology. In Archaeological Geology of North America, edited by N. P. Lasca and J. Donahue, pp. 585-595. Centennial Special Volume 4. Geological Society of America, Boulder, Colorado.

Hofman, J. L.

1984 The Western Protohistoric: A Summary of the Edwards and Wheeler Complexes. In Prehistory of Oklahoma, pp. 347-362. Academic Press, New York.

1989a Prehistoric Culture History: Hunters and Gatherers in the Southern Great Plains. In From Clovis to Comanchero: Archeological Overview of the Southern Great Plains, by J. L. Hofman, R. L. Brooks, J. S. Hays, D. W. Owsley, R. L. Jantz, M. K. Marks, and M. H. Manhein, pp. 25-60. Research Series No. 35. Arkansas Archeological Survey, Fayetteville.

1989b Protohistoric Culture History on the Southern Great Plains. In From Clovis to Comanchero: Archeological Overview of the Southern Great Plains, by J. L. Hofman, R. L. Brooks, J. S. Hays, D. W. Owsley, R. L. Jantz, M. K. Marks, and M. H. Manhein, pp. 91-100. Research Series No. 35. Arkansas Archeological Survey, Fayetteville.

Hofman, J. L., R. L. Brooks, J. S. Hays, D. W. Owsley, R. L. Jantz, M. K. Marks, and M. H. Manhein

1989 From Clovis to Comanchero: Archeological Overview of the Southern Great Plains. Research Series No. 35. Arkansas Archeological Survey, Fayetteville.

Hudson, C. M.

1986 Hernando de Soto in the Caddo Area. Paper presented at the 28th Caddo Conference, Little Rock, Arkansas. 
Hughes, J. T.

1978 Archaeology of Palo Duro Canyon. Panhandle-Plains Historical Review 51:35-58.

1991 Prehistoric Cultural Developments on the Texas High Plains. Bulletin of the Texas Archeological Society 60 (for 1989):1-55.

Hughes, J. T., and P. S. Willey

1978 Archeology at MacKenzie Reservoir. Archeological Survey Report 24. Office of the State Archeologist, Texas Historical Commission, Austin.

Humphrey, J. D., and C. R. Ferring

1994 Stable Isotopic Evidence for Latest Pleistocene and Holocene Climatic Change in North-Central Texas. Quaternary Research 41:200-213.

Hunt, S. M.

1991 Archeological Survey of the Proposed Village/Rush Creek Greenspace Development, Arlington, Texas. Miscellaneous Reports of Investigations No. 25. Geo-Marine, Inc., Plano, Texas.

1993 Intensive Survey of Portions of a Proposed North Texas Municipal Water District Water Treatment Plant, Collin County, Texas. Miscellaneous Reports of Investigations No. 55. Geo-Marine, Inc., Plano, Texas.

1997 Cultural Resource Survey of the Proposed Southwest Arlington Sports Center, City of Arlington, Tarrant County, Texas. Miscellaneous Reports of Investigations No. 142. Geo-Marine, Inc., Plano, Texas.

Hunt, S. M., and M. B. Cliff

1998 Intensive Pedestrian Survey at the Texas Parks and Wildlife Department's 178-acre Pelton Tract, City of Rowlett, Dallas County, Texas. Miscellaneous Reports of Investigations No. 170. Geo-Marine, Inc., Plano, Texas.

Hunt, S. M., and K. A. Krapf

1996 Cultural Resources Survey of the Proposed Tri-City Park, City of Arlington, Tarrant County, Texas. Miscellaneous Reports of Investigations No. 136. Geo-Marine, Inc., Plano, Texas.

Hunt, S. M., and D. E. Peter

1993a Cultural Resources Assessment of the Proposed Rush Creek Linear and Neighborhood Parks, City of Arlington, Tarrant County, Texas. Miscellaneous Reports of Investigations No. 44. Geo-Marine, Inc., Plano, Texas.

1993b Cultural Resources Investigation of Improvements to Cravens Park, City of Arlington, Tarrant County, Texas. Miscellaneous Reports of Investigations No. 52. Geo-Marine, Inc., Plano, Texas. 
1995 Cultural Resources Survey of the Proposed Bowman Springs Road Park, City of Arlington, Tarrant County, Texas. Miscellaneous Reports of Investigations No. 91. Geo-Marine, Inc., Plano, Texas.

1996a Cultural Resources Survey of the Recreation Partnership Initiative Project at Lakes Lavon and Bardwell, Collin and Ellis Counties, Texas. Miscellaneous Reports of Investigations No. 121. Geo-Marine, Inc., Plano, Texas.

1996b Intensive Pedestrian Survey of the Proposed Wylie Pipeline, Collin County, Texas. Miscellaneous Reports of Investigations No. 144. Geo-Marine, Inc., Plano, Texas.

1996c Cultural Resources Survey of the Proposed East Arlington Neighborhood Park, City of Arlington, Tarrant County, Texas. Miscellaneous Reports of Investigations No. 129. Geo-Marine, Inc., Plano, Texas.

1997a Cultural Resources Survey of the Proposed Highway 190 Project Between IH-35E and IH-635, Dallas County, Texas. Miscellaneous Reports of Investigations No. 138. Geo-Marine, Inc., Plano, Texas.

1997b Cultural Resources Survey of the Proposed Randol Mill Road Extension, Phase 1, City of Fort Worth, Tarrant County, Texas. Miscellaneous Reports of Investigations No. 145. Geo-Marine, Inc., Plano, Texas.

1997c Cultural Resources Survey of the Proposed Randol Mill Road Extension, Phase 2, City of Fort Worth, Tarrant County, Texas. Miscellaneous Reports of Investigations No. 146. Geo-Marine, Inc., Plano, Texas.

1998a Intensive Pedestrian Survey and Geoarcheological Investigations of the Proposed Princeton Lift Station Project, Collin County, Texas. Miscellaneous Reports of Investigations No. 163. Geo-Marine, Inc., Plano, Texas.

1998b Cultural Resources Survey of the Proposed Highland Station Park, City of Saginaw, Tarrant County, Texas. Miscellaneous Reports of Investigations No. 166. GeoMarine, Inc., Plano, Texas.

Hunt, S. M., and D. E. Peter (with contributions by K. Wright)

1996 Cultural Resources Survey of the Proposed Kelly Elliott Road Park, City of Arlington, Tarrant County, Texas. Miscellaneous Reports of Investigations No. 123. Geo-Marine, Inc., Plano, Texas.

Hunt, S. M., D. E. Peter, and S. N. Allday

1991 An Archeological Assessment of a Proposed North Texas Municipal Water District Water Line, Collin County, Texas. Miscellaneous Reports of Investigations No. 29. Geo-Marine, Inc., Plano, Texas. 
Hunt, S. M., D. E. Peter, and S. Gaither

1995 Intensive Pedestrian Survey of a Proposed 22-Acre Borrow Pit near the Lake Ray Roberts Dam, Denton County, Texas. Miscellaneous Reports of Investigations No. 102. Geo-Marine, Inc., Plano, Texas.

Hunt, S. M., D. E. Peter, and M. M. Green

1994 Cultural Resources Survey of the Proposed Lynn Creek Linear and Neighborhood Parks, City of Arlington, Tarrant County, Texas. Miscellaneous Reports of Investigations No. 72. Geo-Marine, Inc., Plano, Texas.

Hunt, S. M., D. E. Peter, and K. Morrell

1996 Cultural Resources Survey of Portions of the Westside Recycling and Disposal Facility, Tarrant County, Texas. Miscellaneous Reports of Investigations No. 134. Geo-Marine, Inc., Plano, Texas.

Hunt, S. M., D. E. Peter, and D. K. Shepard

1993 Phase II Cultural Resources Assessment of Railtran Commuter Line, South Irving Transit Station to Station 130+00, Dallas and Tarrant Counties, Texas. Miscellaneous Reports of Investigations No. 47. Geo-Marine, Inc., Plano, Texas.

Hunt, S. M., D. Shanabrook, and D. E. Peter

1991 Archeological Assessment of the Dallas County Utility and Reclamation District Water Development Project. Miscellaneous Reports of Investigations No. 24. GeoMarine, Inc., Plano, Texas.

1992 Cultural Resources Investigations at the City of McKinney Solid Waste Disposal Site, Collin County, Texas. Miscellaneous Reports of Investigations No. 35. GeoMarine, Inc., Plano, Texas.

Hunt, S. M., W. D. White, Jr., and S. Gaither

1996 Intensive Pedestrian Survey of the Proposed Trinity River Greenbelt, Denton County, Texas. Miscellaneous Reports of Investigations No. 117. Geo-Marine, Inc., Plano, Texas.

Jadrosich, J.

1996 Navigation: A Lost Dream for Upper Trinity Basin. Dispatch 14(2):4-5.

Jelks, E. B. (editor)

1967 The Gilbert Site: A NorteZo Focus Site in Northeastern Texas. Bulletin of the Texas Archeological Society, Volume 37 (for 1966).

Jensen, H. P., Jr.

1968 Report on Excavations at the Field Ranch Site (X41CO10), Cooke County, Texas. Bulletin of the Texas Archeological Society 39:133-146. 
John, E. A. H.

1975 Storms Brewed in Other Men's Worlds: The Confrontation of Indians, Spanish, and French in the Southwest, 1540-1795. University of Nebraska Press, Lincoln.

Johnson, L., Jr.

1989 Great Plains Interlopers in the Eastern Woodlands During Late Paleo-Indian Times: The Evidence from Oklahoma, Texas, and Areas Close By. Report No. 36. Office of the State Archeologist, Texas Historical Commission, Austin.

Jurney, D. H.

1987a Preliminary Report of Environmental Characteristics Inventory for the Plano Line from the Martel Portal to Northwest Highway. Archaeology Research Program, Southern Methodist University, Dallas. Cited in Appendix A, Archaeological Investigations of the South Oak Cliff Line and DART Cultural Resources Management, vol. I, by S. A. Skinner, B. B. Whorton, L. K. Trask, R. Scott, S. C. Caran, and J. S. Dillon. AR Consultants, Dallas. Submitted to Dallas Area Rapid Transit, Dallas.

1987b Red Bird Bus Station Archaeological Resources Impact Analysis Technical Memorandum. Archaeology Research Program, Southern Methodist University, Dallas. Cited in Appendix A, Archaeological Investigations of the South Oak Cliff Line and DART Cultural Resources Management, vol. I, by S. A. Skinner, B. B. Whorton, L. K. Trask, R. Scott, S. C. Caran, and J. S. Dillon. AR Consultants, Dallas. Submitted to Dallas Area Rapid Transit, Dallas.

1987c Garland Bus Station Archaeological Resources Impact Analysis Technical Memorandum. Archaeology Research Program, Southern Methodist University, Dallas. Cited in Appendix A, Archaeological Investigations of the South Oak Cliff Line and DART Cultural Resources Management, vol. I, by S. A. Skinner, B. B. Whorton, L. K. Trask, R. Scott, S. C. Caran, and J. S. Dillon. AR Consultants, Dallas. Submitted to Dallas Area Rapid Transit, Dallas.

1987d Garland Transit Center Archaeological Resources Impact Analysis Technical Memorandum. Archaeology Research Program, Southern Methodist University, Dallas. Cited in Appendix A, Archaeological Investigations of the South Oak Cliff Line and DART Cultural Resources Management, vol. I, by S. A. Skinner, B. B. Whorton, L. K. Trask, R. Scott, S. C. Caran, and J. S. Dillon. AR Consultants, Dallas. Submitted to Dallas Area Rapid Transit, Dallas.

Jurney, D. H. (with contributions by J. McElhaney)

1987 Red Bird Transit Center Archaeological Resources Impact Analysis Technical Memorandum. Archaeology Research Program, Southern Methodist University, Dallas. Submitted to Parsons Brinckerhoff Centec, Inc./DeLeuw, Cather \& Company (PBDC), Dallas, Contract Number SC 87-78, Task 87-07. Reproduced in Archaeological Investigations of the South Oak Cliff Line and DART Cultural Resources Management, vol. II, by S. A. Skinner, B. B. Whorton, L. K. Trask, R. Scott, S. C. Caran, and J. S. Dillon. AR Consultants, Dallas. Submitted to Dallas Area Rapid Transit, Dallas. 
1988 North Garland Transit Center Archaeological Resources Impact Analysis Technical Memorandum. Archaeology Research Program, Southern Methodist University, Dallas. Submitted to Parsons Brinckerhoff Centec, Inc./DeLeuw, Cather \& Company (PBDC), Dallas, Contract Number SC 87-78, Task 87-07. Reproduced in Archaeological Investigations of the South Oak Cliff Line and DART Cultural Resources Management, vol. II, by S. A. Skinner, B. B. Whorton, L. K. Trask, R. Scott, S. C. Caran, and J. S. Dillon. AR Consultants, Dallas. Submitted to Dallas Area Rapid Transit, Dallas.

Jurney, D. H. (with contributions by J. McElhaney and D. Payton)

1987 Plano Line Archaeological Resources Impact Analysis Technical Memorandum, P310 State Street Station and City Place Station. Archaeology Research Program, Southern Methodist University, Dallas. Submitted to Parsons Brinckerhoff Centec, Inc./DeLeuw, Cather \& Company (PBDC), Dallas, Contract Number SC 87-78, Task 87-04.

Jurney, D. H. (with contributions by R. W. Moir, J. McElhaney, D. Payton, and M. McKnight)

1988 Archaeological Resources Environmental Characteristics Inventory South Oak Cliff Line Main Street to Camp Wisdom Road. Archaeology Research Program, Southern Methodist University, Dallas. Submitted to Parsons Brinckerhoff Centec, Inc./DeLeuw, Cather \& Company (PBDC), Dallas, Contract Number SC 87-78, Task No. 88-01, Charge No. 52030.

Jurney, D. H., and S. L. Andrews (with contributions by D. C. Dirkmaat, D. Dorward, M. M. Green, C. Kubaas, J. McElhaney, R. W. Moir, D. Payton, C. L. Pedler, and B. Yates)

1994 Archaeological Investigations at 41DL279, Site of the John F. Kennedy Exhibit, Dallas County Administration Building, Dallas, Texas. Archeology Research Program of Mercyhurst Archaeological Institute, Mercyhurst College, Erie, Pennsylvania. Report prepared for Southern Methodist University and the Dallas County Historical Foundation, Dallas. Texas Antiquities Permit Nos. 671 and 671A.

Jurney, D. H., S. A. Lebo, and M. M. Green (compilers)

1988 Historic Farming on the Hogwallow Prairies: Ethnoarcheological Investigations of the Mountain Creek Area, North Central Texas. Joe Pool Lake Archaeological Project, vol. II. Archaeology Research Program, Southern Methodist University, Dallas.

Jurney, D. H., J. McElhaney, and G. M. Weston

1990 Archaeological Resources Impact Potential of North Central Line, Dallas, Texas. Archaeology Research Program, Southern Methodist University, Dallas. Reproduced in Archaeological Investigations of the South Oak Cliff Line and DART Cultural Resources Management, vol. II, by S. A. Skinner, B. B. Whorton, L. K. Trask, R. Scott, S. C. Caran, and J. S. Dillon. AR Consultants, Dallas. Submitted to Dallas Area Rapid Transit, Dallas. 
Jurney, D. H., and R. W. Moir

1987 Preliminary Assessment of the Environmental Characteristics for the Elm Versus Pacific Study. Archaeology Research Program, Southern Methodist University, Dallas. Submitted to Parsons Brinckerhoff Centec, Inc./DeLeuw, Cather \& Company (PBDC), Dallas, Contract Number SC 87-78, Task No. 87-06, Charge No. 43122.

Jurney, D. H., and R. W. Moir (editors)

1987 Historic Buildings, Material Culture, and People of the Prairie Margin. Richland Creek Technical Series, vol. V. Archaeology Research Program, Southern Methodist University, Dallas.

Jurney, D. H., and R. W. Moir (with contributions by J. McElhaney)

1987 Archaeological Resources Plano 320 Preliminary Impact Analysis. Archaeology Research Program, Southern Methodist University, Dallas. Submitted to Parsons Brinckerhoff Centec, Inc./DeLeuw, Cather \& Company (PBDC) Environmental Planning, Dallas, Task No. 87-04, Charge No. 46103.

Jurney, D. H., and R. W. Moir (with contributions by J. McElhaney and D. Payton) 1987 Archaeological Resources Preliminary Design Impact Analysis Technical Memorandum, Contract Segment P320. Archaeology Research Program, Southern Methodist University, Dallas. Submitted to Parsons Brinckerhoff Centec, Inc./DeLeuw, Cather \& Company (PBDC), Dallas, Contract Number SC 87-78, Task No. 87-04.

Jurney, D. H., R. W. Moir, D. Dorward, and G. M. Weston (with contributions by J. Girard, S. Linder-Linsley, D. Payton, and B. Young)

1990 Archaeological Resources Impact Potential of South Oak Cliff Alternatives, Dallas, Texas. Archaeology Research Program, Southern Methodist University, Dallas. Submitted to Parsons Brinckerhoff Centec, Inc./DeLeuw, Cather \& Company (PBDC), Dallas, Task No. 90-01.

Jurney, D. H., R. W. Moir, D. Dorward, and G. M. Weston (with contributions by J. Girard, S. Linder-Linsley, J. McElhaney, D. Payton, F. Winchell, and B. Young)

1991 Archaeological Resources Impact Potential of the South Oak Cliff Locally Preferred Alternative, Dallas, Texas. Archaeology Research Program, Southern Methodist University, Dallas. Submitted to Huitt-Zollars; Parsons Brinckerhoff, Inc., Dallas, Task 18, Subcontract No. SCR 90-037. Reproduced in Archaeological Investigations of the South Oak Cliff Line and DART Cultural Resources Management, vol. II, by S. A. Skinner, B. B. Whorton, L. K. Trask, R. Scott, S. C. Caran, and J. S. Dillon. AR Consultants, Dallas. Submitted to Dallas Area Rapid Transit, Dallas. 
Jurney, D. H., R. W. Moir, and D. E. Peter (with contributions by J. McElhaney, D. Payton, and J. Girard)

1987 Archaeological Resources Preliminary Assessment of Resource Characteristics P310 Draft Report. Archaeology Research Program, Southern Methodist University, Dallas. Submitted to Parsons Brinckerhoff Centec, Inc./DeLeuw, Cather \& Company (PBDC) Environmental Planning, Dallas, Task No. 87-04, Charge No. 46103.

Jurney, D. H., D. E. Peter, and J. McElhaney

1987 Archaeological Resources Overview of Resources Characteristics, Plano Line, Union Station to Texas Instruments. Archaeology Research Program, Southern Methodist University, Dallas. Cited in Appendix A, Archaeological Investigations of the South Oak Cliff Line and DART Cultural Resources Management, vol. I, by S. A. Skinner, B. B. Whorton, L. K. Trask, R. Scott, S. C. Caran, and J. S. Dillon. AR Consultants, Dallas. Submitted to Dallas Area Rapid Transit, Dallas.

Jurney, D. H., D. E. Peter, and J. McElhaney (with contributions by D. Payton and J. Girard)

1988 Archaeological Resources Overview of Resource Characteristics, Plano Line, Union Station to Texas Instruments. Archaeology Research Program, Southern Methodist University, Dallas. Submitted to Parsons Brinckerhoff Centec, Inc./DeLeuw, Cather \& Company (PBDC) Environmental Planning, Dallas, Task No. 87-04, Charge No. 46103.

Jurney, D. H., D. E. Peter, J. McElhaney, D. Payton, and J. Girard

1987 Archaeological Resources Overview of Resources Characteristics, Plano Line, Draft Report. Archaeology Research Program, Southern Methodist University, Dallas. Submitted to Parsons Brinckerhoff Centec, Inc./DeLeuw, Cather \& Company (PBDC) Environmental Planning, Dallas, Task No. 87-04, Charge No. 46103.

Katz, S. R., and P. R. Katz

1976 Archaeological Investigations in the Lower Tule Canyon, Briscoe County, Texas. Survey Report No. 16. Office of the State Archaeologist, Texas Historical Commission, Austin.

Knox, J. C.

1972 Valley Alluviation in Southwestern Wisconsin. Annals of the American Association of Geographers 62(3):401-10.

Krapf, K. A., and S. M. Hunt

1996 Cultural Resources Survey of the Proposed Village of Fossil Creek Housing Development, Tarrant County, Texas. Miscellaneous Reports of Investigations No. 143. Geo-Marine, Inc., Plano, Texas.

Krieger, A. D.

1946 Culture Complexes and Chronology in Central Texas with Extension of Puebloan Dating to the Mississippi Valley. Publication No. 4640. University of Texas, Austin. 
1947 The Eastward Extension of Puebloan Datings Toward Cultures of the Mississippi Valley. American Antiquity 12(3):141-148.

Largent, F. B., Jr., S. M. Hunt, and D. E. Peter (with contributions by K. A. Krapf and D. Shanabrook)

1994 Cultural Resource Investigations at the East First Street Bridge, Fort Worth, Tarrant County, Texas. Miscellaneous Reports of Investigations No. 74. Geo-Marine, Inc., Plano, Texas.

Lebo, S. A. (editor)

1995a Archaeology of Nineteenth and Early Twentieth Centuries Lifeways in the Lewisville Lake Area, Denton County, Texas. Institute of Applied Sciences, University of North Texas, Denton.

1995b Archaeology and History of the Lake Ray Roberts Area of Northcentral Texas, 1850-1950. Institute of Applied Sciences, University of North Texas, Denton.

Lebo, S. A., and K. L. Brown

1990 Archaeological Survey of the Lewisville Lake Shoreline, Denton County, Texas. Institute of Applied Sciences, University of North Texas, Denton.

Lorrain, D. H., and N. Hoffrichter

1968 The Lower Rockwall Site, Rockwall County, Texas. Salvage Project, Southern Methodist University, Dallas. Submitted to the National Park Service.

Lynott, M. J.

1975 Archaeological Excavations at Lake Lavon 1974. Contribution in Anthropology No. 16. Archaeology Research Program, Southern Methodist University, Dallas.

1977 A Regional Model for Archaeological Research in Northcentral Texas. Unpublished Ph.D. dissertation, Department of Anthropology, Southern Methodist University, Dallas.

Lynott, M. J., T. W. Boutton, J. E. Price, and D. E. Nelson

1986 Stable Carbon Isotopic Evidence for Maize Agriculture in Southeast Missouri and Northeast Arkansas. American Antiquity 51(1):51-65.

McCormick, O.

1976 An Archaeological Reconnaissance of Fivemile Creek Floodplain. Institute of Applied Sciences, North Texas State University, Denton.

McElhaney, J.

1995 Navigating the Trinity. In Dallas Reconsidered: Essays in Local History, edited by M. V. Hazel. Three Forks Press, Dallas. 
McGregor, D. E.

1988 Archaeological Background. In Late Holocene Prehistory of the Mountain Creek Drainage, edited by D. E. Peter and D. E. McGregor, pp. 27-33. Joe Pool Lake Archaeological Project, vol. I. Archaeology Research Program, Southern Methodist University, Dallas.

McGregor, D. E., and J. E. Bruseth (editors)

1987 Hunter-Gather Adaptations along the Prairie Margin: Site Excavations and Synthesis of Prehistoric Archaeology. Richland Creek Technical Series, vol. III. Archaeology Research Program, Southern Methodist University, Dallas.

McMahan, C. A., R. G. Frye, and K. L. Brown

1984 The Vegetation Types of Texas, Including Cropland (Illustrated Synopsis and Map). Wildlife Division, Texas Parks and Wildlife Department, Austin.

Meltzer, D. J.

1987 The Clovis Paleoindian Occupation of Texas: Results of the Texas Clovis Fluted Point Survey. Bulletin of the Texas Archeological Society 57:27-68.

Meltzer, D. J., and M. R. Bever

1995 Paleoindians of Texas: An Update on the Texas Clovis Fluted Point Survey. Bulletin of the Texas Archeological Society 66:47-81.

Meltzer, D. J., and B. D. Smith

1986 Paleoindian and Early Archaic Subsistence Strategies in Eastern North America. In Foraging, Collecting and Harvesting: Archaic Period Subsistence and Settlement in the Eastern Woodlands, edited by S. W. Neusius, pp. 3-31. Occasional Paper No. 6. Center for Archaeological Investigations, Southern Illinois University, Carbondale.

Moir, R. W., D. Dorward, and F. Winchell (with contributions by D. Dorward, W. Dorward, S. Mbutu, and D. H. Jurney)

1991 Summary of Intensive Archaeological Survey of the South Oak Cliff Locally Preferred Alternative Light Rail Transit Line. Archaeology Research Program, Southern Methodist University, Dallas. Submitted to Huitt-Zollars and Parsons Brinckerhoff, Inc., Dallas, Task 18.

Moir, R. W., and D. H. Jurney

1987 Archaeological Resources Impact Potential of P100 Alternatives CBD [Central Business District], Dallas. Archaeology Research Program, Southern Methodist University, Dallas. Submitted to Parsons Brinckerhoff Centec, Inc./DeLeuw, Cather \& Company (PBDC), Dallas, Contract Number SC 87-78, Task 87-08.

Moir, R. W., and D. H. Jurney (editors)

1987 Pioneer Settlers, Tenant Farmers, and Communities: Objectives, Historical Background, and Excavations. Richland Creek Technical Series, vol. IV. Archaeology Research Program, Southern Methodist University, Dallas. 
Moir, R. W., and D. H. Jurney (with contributions by D. Dorward, J. Girard, J. McElhaney, D. Payton, and D. Peter)

1988 Archaeological Resources Impact Potential of P100 Alternatives CBD, Dallas, Plano Line, Final Report. Archaeology Research Program, Southern Methodist University, Dallas. Submitted to Parsons Brinckerhoff Centec, Inc./DeLeuw, Cather \& Company (PBDC), Dallas, Contract Number SC 87-78, Task No. 87-08. Reproduced in Archaeological Investigations of the South Oak Cliff Line and DART Cultural Resources Management, by S. A. Skinner, B. B. Whorton, L. K. Trask, R. Scott, S. C. Caran, and J. S. Dillon. AR Consultants, Dallas. Submitted to Dallas Area Rapid Transit, Dallas.

Moir, R. W., and D. E. Peter

1987 Archaeological Pedestrian Survey and Literature Review of the Proposed South Irving Transit Center Location, Irving, Texas. Archaeology Research Program, Southern Methodist University, Dallas. Submitted to Parsons Brinckerhoff Centec, Inc./DeLeuw, Cather \& Company (PBDC), Dallas.

Moir, R. W., D. E. Peter, and D. H. Jurney (with contributions by J. Girard, J. McElhaney, and D. Payton)

1987a Preliminary Report of Design Impact Analysis for the Plano Line, Section P 100: Main Street to Lamar Street. Archaeology Research Program, Southern Methodist University, Dallas. Submitted to Parsons Brinckerhoff Centec, Inc./DeLeuw, Cather \& Company (PBDC), Dallas, Contract Number SC 87-78, Task No. 87-02.

1987b FP100 Archaeological Resources Impact Analysis Technical Memorandum. Archaeology Research Program, Southern Methodist University, Dallas. Reproduced in Archaeological Investigations of the South Oak Cliff Line and DART Cultural Resources Management, by S. A. Skinner, B. B. Whorton, L. K. Trask, R. Scott, S. C. Caran, and J. S. Dillon. AR Consultants, Dallas. Submitted to Dallas Area Rapid Transit, Dallas.

Morgan, L. W.

1975 An Empirical Analysis of a Pre-Neo-American Site in Dallas County, Texas. Unpublished Master's thesis, Department of Anthropology, University of Texas at Arlington.

Morris, V., and B. Morris

1970 Excavation of Bison Remains in Northwest Dallas County. The Record 27(1):2-5.

Myra L. Frank \& Associates

1987a FP100 Historic Resources Impact Analysis. Myra L. Frank \& Associates, Los Angeles. Submitted to Parsons Brinckerhoff Centec, Inc./DeLeuw, Cather \& Company (PBDC) Environmental Planning, Dallas.

1987b Historic Properties Effects Report. Appendix C in South Irving Transit Center Environmental Assessment. Parsons Brinckerhoff Centec, Inc./DeLeuw, Cather \& Company (PBDC), Dallas. 
1987c FP310 Historic Resources Preliminary Design Impact Analysis. Myra L. Frank \& Associates, Los Angeles. Submitted to Parsons Brinckerhoff Centec, Inc./DeLeuw, Cather \& Company (PBDC) Environmental Planning, Dallas, Charge No. 46103, Document Control No. CR6Y-101-00 0000 F 09/14/87.

1988a Elm/Pacific Environmental Studies Summary. Myra L. Frank \& Associates, Los Angeles. Submitted to Parsons Brinckerhoff Centec, Inc./DeLeuw, Cather \& Company (PBDC) Environmental Planning, Dallas.

1988b Historic Resources Supplemental Environmental Characteristics Inventory Pacific Avenue vs. Elm Street Study, Contract Segment-Pacific vs. Elm. Myra L. Frank \& Associates, Los Angeles. Submitted to Parsons Brinckerhoff Centec, Inc./DeLeuw, Cather \& Company (PBDC) Environmental Planning, Dallas, Task No. 88-02, Charge No. 43129.

1988c Historic Resources Impact Analysis Pacific Avenue vs. Elm Street Study. Myra L. Frank \& Associates, Los Angeles. Submitted to Parsons Brinckerhoff Centec, Inc./DeLeuw, Cather \& Company (PBDC) Environmental Planning, Dallas, Charge No. 43129, Document Control No. CR6N-02500 0000 E 06/00/88.

1988d P320 Historic Resources Preliminary Design Impact Analysis. Myra L. Frank \& Associates, Los Angeles. Submitted to Parsons Brinckerhoff Centec, Inc./DeLeuw, Cather \& Company (PBDC) Environmental Planning, Dallas, Charge No. 46103, Document Control No. CR6Y-234-01 0688 D 08/19/87.

1988e Historic Resources Inventory South Oak Cliff Line Iowa Avenue to Camp Wisdom Road Via the East Lancaster Alignment. Myra L. Frank \& Associates, Los Angeles. Submitted to Parsons Brinckerhoff Centec, Inc./DeLeuw, Cather \& Company (PBDC) AA/DEIS, Dallas, Charge No. 53020.

1990 Historic Resources Environmental Characteristics Inventory, South Oak Cliff Line (from Camp Wisdom Road to North Central Expressway). Myra L. Frank \& Associates, Los Angeles. Submitted to Parsons Brinckerhoff Centec, Inc./DeLeuw, Cather \& Company (PBDC) Environmental Planning, Dallas.

1993 Veterans Administration Hospital, Section 106 and Section 4(f) Report, South Oak Cliff Corridor. Myra L. Frank \& Associates, Los Angeles. Submitted to Huitt-Zollars, Inc., and Dallas Area Rapid Transit, Dallas.

Myra L. Frank \& Associates and ArchiTexas

1987 South Irving Transit Center Historic Resources Determination of Eligibility Report. Myra L. Frank \& Associates, Los Angeles, and ArchiTexas, Dallas. Submitted to Parsons Brinckerhoff Centec, Inc./DeLeuw, Cather \& Company (PBDC), Dallas. 
1988 Historic Resources Environmental Characteristics Inventory South Oak Cliff Line (Main Street to Iowa Avenue), Contract Segment 87-76. Myra L. Frank \& Associates, Los Angeles, and ArchiTexas, Dallas. Submitted to Parsons Brinckerhoff Centec, Inc./DeLeuw, Cather \& Company (PBDC) Environmental Planning, Dallas, Task No. No. 88-01, Charge No. 146202.

Myra L. Frank \& Associates and Burson \& Cox Architects, Inc.

1987a Historic Resources Environmental Characteristics Inventory Plano Line, Contract Segment-F.P. 320. Myra L. Frank \& Associates, Los Angeles, and Burson \& Cox Architects, Inc., Dallas. Submitted to Parsons Brinckerhoff Centec, Inc./DeLeuw, Cather \& Company (PBDC) Environmental Planning, Dallas, Task No. 87-03, Charge No. 49001.

1987b Historic Resources Environmental Characteristics Inventory Plano Line, Contract Segment-North Dallas. Myra L. Frank \& Associates, Los Angeles, and Burson \& Cox Architects, Inc., Dallas. Submitted to Parsons Brinckerhoff Centec, Inc./DeLeuw, Cather \& Company (PBDC) Environmental Planning, Dallas, Task No. 87-01, Charge No. 41010.

1987c Historic Resources Environmental Characteristics Inventory Plano Line, Contract Segment-Downtown. Myra L. Frank \& Associates, Los Angeles, and Burson \& Cox Architects, Inc., Dallas. Submitted to Parsons Brinckerhoff Centec, Inc./DeLeuw, Cather \& Company (PBDC) Environmental Planning, Dallas, Task No. 87-01, Charge No. 41010.

1987d Historic Resources Environmental Characteristics Inventory Plano Line, Contract Segment FP310. Myra L. Frank \& Associates, Los Angeles, and Burson \& Cox Architects, Inc., Dallas. Submitted to Parsons Brinckerhoff Centec, Inc./DeLeuw, Cather \& Company (PBDC) Environmental Planning, Dallas, Task No. 87-03, Charge No. 41010.

Newcomb, W. W., Jr.

1993 Historic Indians of Central Texas. Bulletin of the Texas Archeological Society 64:163.

Nunley, P.

1973 An Assessment of Archeological Resources in the Vicinity of Garza-Little Elm Reservoir. Miscellaneous Papers No. 1. Richland Archeological Society, Richland College, Dallas.

Peter, D. E., and M. B. Cliff

1988 Archeological Survey of the Proposed Flood Control Project Along Johnson Creek, Grand Prairie and Arlington, Texas. Miscellaneous Reports of Investigations No. 1. Geo-Marine, Inc., Plano, Texas. 
Peter, D. E., M. B. Cliff, J. Freeman, J. McElhaney, and S. N. Allday

1991 Phase I Cultural Resources Assessment of Railtran Commuter Line, South Irving Station to Union Station, Dallas County, Texas. Miscellaneous Reports of Investigations No. 18. Geo-Marine, Inc., Plano, Texas.

Peter, D. E., M. B. Cliff, S. M. Hunt, and S. N. Allday

1990 Cultural Resources Survey of the North McKinney Interceptor Sewer, Collin County, Texas. Miscellaneous Reports of Investigations No. 19. Geo-Marine, Inc., Plano, Texas.

Peter, D. E., and V. G. Clow

2000 An Archeological and Osteological Investigation of 41DL373, Spring Creek Park Preserve, Dallas County, Texas. Miscellaneous Reports of Investigations No. 186. Geo-Marine, Inc., Plano, Texas.

Peter, D. E., B. Ellwood, J. Scheiber, and B. Yates

1987 Test Excavations of the River Bend Site (41TR68). Center for Geoarchaeological Studies, University of Texas at Arlington.

Peter, D. E., and S. Gaither

1990 Archeological Survey of the Proposed Northeast Arlington Neighborhood/ Community Park, Arlington, Texas. Miscellaneous Reports of Investigations No. 16. Geo-Marine, Inc., Plano, Texas.

Peter, D. E., S. M. Hunt, and M. M. Green

1994 Intensive Survey of a Portion of Zoo Creek, Tarrant County, Texas. Miscellaneous Reports of Investigations No. 68. Geo-Marine, Inc., Plano, Texas.

Peter, D. E., F. B. Largent, Jr., and S. M. Hunt (with contributions by K. Krapf and D. Shanabrook)

1998 Cultural Resources Impact Assessment of the Proposed Randol Mill Road Extension, Phase 3, City of Fort Worth, Tarrant County, Texas. Miscellaneous Reports of Investigations No. 159. Geo-Marine, Inc., Plano, Texas.

Peter, D. E., and D. E. McGregor (editors)

1988 Late Holocene Prehistory of the Mountain Creek Drainage. Joe Pool Lake Archaeological Project, vol. I. Archaeology Research Program, Southern Methodist University, Dallas.

Peter, D. E., M. Prior, M. M. Green, and V. Clow (editors)

2000 Freedman's Cemetery: A Legacy of A Pioneer Black Community in Dallas, Texas. Submitted to the Texas Department of Transportation. TxDOT, Environmental Affairs Division, Archeology Studies Program, Report No. 21. Special Publication No. 6. Geo-Marine, Inc., Plano, Texas. 
Peter, D. E., D. Shepard, and S. M. Hunt

1994 An Evaluation for the Potential Presence of Historic Properties Located within the North Campus Expansion Area of the University of Texas Southwestern Medical Center, Dallas, Texas. Miscellaneous Reports of Investigations No. 64. GeoMarine, Inc., Plano, Texas.

Prewitt, E. R.

1981 Cultural Chronology in Central Texas. Bulletin of the Texas Archeological Society 52:65-89.

1985 From Circleville to Toyah: Comments on Central Texas Chronology. Bulletin of the Texas Archeological Society 54 (for 1982):201-238.

Prikryl, D. J.

1990 Lower Elm Fork Prehistory: A Redefinition of Cultural Concepts and Chronologies along the Trinity River, North-Central Texas. Report 37. Office of the State Archeologist, Texas Historical Commission, Austin.

1993 Introduction to Section III: Regional Preservation Plan for Archeological Resources, Prairie-Savanna Archeological Region. In Archeology in the Eastern Planning Region, Texas: A Planning Document, edited by N. A. Kenmotsu and T. K. Perttula, pp. 191-204. Cultural Resource Management Report 3. Department of Antiquities Protection, Texas Historical Commission, Austin.

Prikryl, D. J., and B. C. Yates (editors)

1987 Test Excavations at 41CO141, Ray Roberts Reservoir, Cooke County, Texas. Contributions in Archaeology No. 4. Institute of Applied Sciences, North Texas State University, Denton.

Prince, $\mathrm{R}$.

1993 A History of Dallas: From a Different Perspective. Nortex Press, an Imprint of Sunbelt Media, Inc.

Raab, L. M., J. E. Bruseth, and A. J. McIntyre

1980 Archaeological Testing at Lakeview Lake, 1979: Human Use of the Landscape. Archaeology Research Program, Southern Methodist University, Dallas.

Raab, L. M., A. J. McIntyre, J. E. Bruseth, D. E. McGregor, C. R. Ferring, and N. Reese 1982 Archaeological Investigations at Lakeview Lake: 1979 and 1980. Archaeological Monographs Number 2. Archaeology Research Program, Southern Methodist University, Dallas.

Raab, L. M., R. W. Moir, and D. E. McGregor

1980 Preliminary Report of Archaeological Survey in the Richland-Chambers Dam and Reservoir Projects, Navarro and Freestone Counties, Texas. Archaeology Research Program, Southern Methodist University, Dallas. 
1981 Preliminary Report of Archaeological Testing in the Richland-Chambers Dam and Reservoir Projects, Navarro and Freestone Counties, Texas. Archaeology Research Program, Southern Methodist University, Dallas.

Richner, J. J.

1982 Tennessee Colony III. Archaeology Research Program, Southern Methodist University, Dallas.

Richner, J. J., and J. T. Bagot (assemblers)

1978 A Reconnaissance Survey of the Trinity River Basin, 1976-1977. Research Report 113. Archaeology Research Program, Southern Methodist University, Dallas.

Richner, J. J., and R. Lee

1976 Cultural Resources at Tennessee Colony Lake. Archaeology Research Program, Southern Methodist University, Dallas.

1977 Archaeological and Ethnohistorical Survey at Tennessee Colony Lake, 1975. Research Report 104. Archaeology Research Program, Southern Methodist University, Dallas.

Rohn, A. H.

1998 Haley's Point (34MA15) on the Red River, Marshall County, Oklahoma (Area F). Publications in Anthropology No. 4. Wichita State University, Wichita, Kansas.

Rose, J. C., and M. P. Hoffman

1989 Maize Dependency in the Trans-Mississippi South. Paper presented at the 31st Annual Caddo Conference, Norman, Oklahoma, March 3-5.

Ross, R. E.

1966 The Upper Rockwall and Glen Hill Sites, Forney Reservoir. Paper No. 9. Texas Archeological Salvage Project, University of Texas, Austin.

Saunders, J.

1991 Boats Along the Trinity. In Sketches of a Growing Town: Episodes and People of Dallas from Early Days to Recent Times, edited by D. Payne. Southern Methodist University Press, Dallas.

Schambach, F. F.

1989 The End of the Trail: The Route of Hernando De Soto’s Army Through Southwest Arkansas and East Texas. The Arkansas Archeologist 27/28 (for 1986 and 1987):933.

Schmidly, D. J.

1983 Texas Mammals East of the Balcones Fault Zone. Texas A\&M University Press, College Station. 
Shafer, H. J.

1977 Early Lithic Assemblages in Eastern Texas. The Museum Journal 17:187-197. West Texas Museum Association, Lubbock.

Skinner, S. A.

1982a Cultural Resources Survey. The Archaeology and History of Lake Ray Roberts, vol. 1: Cultural Resources Report 82-9. Environment Consultants, Inc., Dallas.

1982b Construction Area Testing. The Archaeology and History of Lake Ray Roberts, vol. 2: Cultural Resources Report 82-86. Environment Consultants, Inc., Dallas.

1990a Cultural Resources Survey of the Rowlett Community Park. Cultural Resources Report 90-1. AR Consultants, Dallas.

1990b A Cultural Resources Survey of the Spring Creek Forest Preserve. Cultural Resources Report 90-2. AR Consultants, Dallas.

1993 Cultural Resources Survey of the Spring Creek Greenbelt. Cultural Resources Report 93-13. AR Consultants, Dallas.

Skinner, S. A., and L. Baird (assemblers)

1985 Settlement in a Marginal Zone. The Archaeology and History of Lake Ray Roberts, vol. 3. AR Consultants, Dallas.

Skinner, S. A., and D. T. Connors

1979 Archaeological Investigations at Lakeview Lake. Research Report 118. Archaeology Research Program, Southern Methodist University, Dallas.

Skinner, S. A., and F. D. Kent

1998 Cultural Resources Investigation of an Elm Fork Wetland Mitigation Area, Irving, Texas. AR Consultants, Dallas. Draft report. Submitted to University of Dallas, Irving, Texas.

Skinner, S. A., L. D. Lindsay, B. B. Whorton, and W. L. Young

1994 Cultural Resources Investigation of Four Station Sites on the West Oak Cliff Line, Dallas, Texas. Cultural Resources Report 92-8. AR Consultants, Dallas.

Skinner, S. A., and B. B. Whorton

1993 Archaeological Survey of the Little Lemmon Lake Project. Cultural Resources Report 93-3. AR Consultants, Dallas.

1995 Monitoring Cultural Resources Exposures at the Central Waste Water Treatment Plant Expansion. Cultural Resources Report 95-15. AR Consultants, Dallas. 
Skinner, S. A., B. B. Whorton, and L. K. Trask

1996 The Archaeological Monitoring of the Dallas Floodway Channel Modifications and Levee Fill Modifications Phase I. Cultural Resources Report 96-19. AR Consultants, Dallas.

Skinner, S. A., B. B. Whorton, L. K. Trask, R. Scott, S. C. Caran, and J. S. Dillon

1996 Archaeological Investigations of the South Oak Cliff Line and DART Cultural Resources Management. 2 vols. Cultural Resources Report 95-1. AR Consultants, Dallas. Submitted to Dallas Area Rapid Transit, Dallas.

Skinner, S. A., B. B. Whorton, and W. L. Young

1991 Cultural Resource Assessment of the Central Waste Water Treatment Plant Flood Protection Study, Dallas, Texas. Cultural Resources Report 91-6. AR Consultants, Dallas.

Skinner, S. A., W. L. Young, B. B. Whorton, and M. B. Collins

1990 Cultural Resource Investigations of the Rochester Park Levee, Dallas, Texas. Cultural Resources Report 90-9. AR Consultants, Dallas.

Slaughter, E. H., and B. R. Hoover

1963 Sulphur River Formation and the Pleistocene Mammals of the Ben Franklin Local Fauna. Journal of the Graduate Research Center 31(3):132-148. Southern Methodist University, Dallas.

Smith, F. T.

1996 The Caddos, the Wichitas, and the United States, 1846-1901. Texas A\&M University Press, College Station.

Sollberger, J. B.

1953 The Humphrey Site. The Record 11(3):11-14.

Stanford, D.

1981 “Who’s On First?” Science 81 2(5):91-92.

Stephenson, R. L.

1949a Archeological Survey of Lavon and Garza-Little Elm Reservoir: A Preliminary Report. Bulletin of the Texas Archeological and Paleontological Society 20:21-62.

1949b Archeological Survey of Lavon Reservoir, Collin County, Texas. River Basin Surveys, Austin Office, Smithsonian Institution.

1950 Archeological Survey of Garza-Little Elm Reservoir, Denton County, Texas. River Basin Surveys, Austin Office, Smithsonian Institution.

1952a The Hogge Bridge Site and the Wylie Focus. American Antiquity 17:299-312. 
1952b The 1950 Excavation in the Lavon Reservoir, Collin County, Texas. River Basin Surveys, Austin Office, Smithsonian Institution.

Story, D. A.

1985 Adaptive Strategies of Archaic Cultures of the West Gulf Coastal Plain. In Prehistoric Food Production in North America, edited by R. I. Ford, pp. 19-56. Anthropological Papers No. 75. Museum of Anthropology, University of Michigan, Ann Arbor.

1990 Cultural History of the Native Americans. In The Archeology and Bioarcheology of the Gulf Coastal Plain, 2 vols., by D. A. Story, J. A. Guy, B. A. Burnett, M. D. Freeman, J. C. Rose, D. G. Steele, B. W. Olive, and K. J. Reinhard, pp. 1:163-1:366. Research Series No. 38. Arkansas Archeological Survey, Fayetteville.

Story, D. A., J. A. Guy, B. A. Burnett, M. D. Freeman, J. C. Rose, D. G. Steele, B. W. Olive, and K. J. Reinhard

1990 The Archeology and Bioarcheology of the Gulf Coastal Plain. 2 vols. Research Series No. 38. Arkansas Archeological Survey, Fayetteville.

Trask, L. K., B. B. Whorton, and S. A. Skinner

1997 Archaeological Monitoring of the West Bank Relief Interceptor, Dallas, Texas. Cultural Resources Report 97-9. AR Consultants, Dallas.

U.S. Department of Agriculture (USDA)

1964 Soil Survey of Ellis County, Texas. U.S. Department of Agriculture, Soil Conservation Service, in cooperation with Texas Agricultural Experiment Station.

1969 Soil Survey of Collin County, Texas. U.S. Department of Agriculture, Soil Conservation Service, in cooperation with Texas Agricultural Experiment Station.

1980 Soil Survey of Dallas County, Texas. U.S. Department of Agriculture, Soil Conservation Service, in cooperation with Texas Agricultural Experiment Station.

Van der Merwe, N. J.

1982 Carbon Isotopes, Photosynthesis, and Archaeology. American Scientist 70:596-606.

Van der Merwe, N. J., and J. Vogel

1977 Isotopic Evidence for Early Maize Cultivation in New York State. American Antiquity 42:238-242.

Vehik, S. C.

1994 Cultural Continuity and Discontinuity in the Southern Prairies and Cross Timbers. In Plains Indians, A.D. 500-1500: The Archaeological Past of Historic Groups, edited by K. H. Schlesier, pp. 239-263. University of Oklahoma Press, Norman. 
Wallace, E., and E. A. Hoebel

1952 The Comanches: Lords of the South Plains. University of Oklahoma Press, Norman.

Webb, W. P., and H. B. Carroll (editors)

1952 The Handbook of Texas. 2 vols. Texas State Historical Association, Austin.

Weber, D. J.

1992 The Spanish Frontier in North America. Yale University Press, New Haven.

Weddle, R. S.

1964 The San Sabá Mission: Spanish Pivot in Texas. University of Texas Press, Austin.

1965 The San Sabá Mission: Approach to the Great Plains. Great Plains Journal 4(2):29-38.

Weston, G. M., and D. Dorward

1990 Archaeological Resources Impact Potential of West Oak Cliff Alternatives, Dallas, Texas. Archaeology Research Program, Southern Methodist University, Dallas. Cited in Appendix A, Archaeological Investigations of the South Oak Cliff Line and DART Cultural Resources Management, vol. I, by S. A. Skinner, B. B. Whorton, L. K. Trask, R. Scott, S. C. Caran, and J. S. Dillon. AR Consultants, Dallas. Submitted to Dallas Area Rapid Transit, Dallas.

Winchell, F., and D. Dorward (with contributions by R. W. Moir)

1991 Preliminary Status Report on Archaeological Testing of the South Oak Cliff Line. Archaeology Research Program, Southern Methodist University, Dallas. Submitted to Huitt-Zollars and Parsons-Brinckerhoff, Dallas.

Word, J. H., and A. A. Fox

1975 The Cogdell Burial in Floyd County, Texas. Bulletin of the Texas Archeological Society 46:1-67.

Works Projects Administration (WPA)

1992 The WPA Dallas Guide and History: Written and Compiled from 1936 to 1942 by the Workers of the Writer's Program of the Works Projects Administration in the City of Dallas. Published jointly by the Dallas Public Library and the University of North Texas Press, Denton.

Yates, B. C., and C. R. Ferring

1986 An Assessment of the Cultural Resources in the Trinity River Basin, Dallas, Tarrant, and Denton Counties, Texas. Institute of Applied Sciences, North Texas State University, Denton. Submitted to the U.S. Army Corps of Engineers, Fort Worth District. 
Geoarcheological Investigations of Wetland Cell D within the Dallas Floodway Extension Project Area, Dallas, Texas 


\section{APPENDIX A}

\section{BACKHOE TRENCH PROFILE DESCRIPTIONS}



Backhoe Trench Profiles

\begin{tabular}{|c|c|c|}
\hline Depth (cm) & Soil Zone & Description \\
\hline \multicolumn{3}{|c|}{ BHT 1 Near NW corner of survey area and $17 \mathrm{~m}$ east of northbound I-45 bridge } \\
\hline $0-48$ & $\mathrm{AC}$ & $\begin{array}{l}\text { Very dark grayish brown (10YR } 3 / 2) \text { clay; firm; massive; abundant rootlets } \\
\text { and woody roots; abundant modern debris (plastic, cellophane, styrofoam, } \\
\text { plastic oil bottles); abrupt boundary }\end{array}$ \\
\hline $48-78$ & 2C & $\begin{array}{l}\text { Brown (10YR 5/3) clayey sand; massive; friable; finely bedded and } \\
\text { laminated; common woody roots and rootlets; abundant modern debris } \\
\text { (plastic, paper, soda cans); abrupt irregular boundary }\end{array}$ \\
\hline $78-223$ & $\begin{array}{l}3 \mathrm{C} \text { to } \\
4 \mathrm{Bb}\end{array}$ & $\begin{array}{l}\text { Upper } 35 \text { to } 45 \mathrm{~cm} \text { consists of mixed chunks of clay of varying colors (very } \\
\text { dark gray [10YR 3/1] to brown [10YR 5/3]); next } 10 \mathrm{~cm} \text { dips east in trench } \\
\text { wall and consists of reddened, burned clay ( } 2.5 \mathrm{YR} 4 / 4) \text { containing pieces of } \\
\text { concrete, construction gravel, some charcoal, plastic; next } 20 \mathrm{~cm} \text { below red } \\
\text { clay, zone is dark gray (10YR 4/1) clay; firm; massive, with common rootlets } \\
\text { and appears disturbed; remainder of zone is dark gray (10YR 4/1) clay; firm; } \\
\text { massive to fine blocky; some black decaying organic matter; few snail shell } \\
\text { fragments blocky }\end{array}$ \\
\hline
\end{tabular}

\section{BHT 2 Center of survey area at north end}

0-46 C

46-112 Fill

$112-135 \quad 2 \mathrm{ACb}$

$135-230 \quad 2 \mathrm{C} 1$

230-280 2C2ca

280-305 3Abca
Dark grayish brown (10YR 4/2) silty, sandy, clay; firm; massive; abundant rootlets; abundant modern debris (plastic and metal); zone may be disturbed or result of recent floods; boundary abrupt and marked by layer of decaying vegetation

Very dark gray (10YR 3/1) clay; firm; massive; common woody roots; few pieces of plastic and construction gravel; some yellow cushion sand; boundary is abrupt and marked by large decaying log and gray (10YR 5/1) sand lenses

Dark grayish brown (10YR 4/2) clay; very firm; blocky with tan silt coats on ped faces; few snail shell fragments; few open rootlet holes; gradual boundary

Grayish brown to brown (10YR 5/2 to 10YR 5/3) sandy clay; blocky with heavy silt coats on ped faces; firm; common open rootlet holes; few orange Fe mottles; sandy content varies with depth; gradual boundary

Dark grayish brown (10YR 4/2) clay; firm; massive to weak blocky; common rootlets and woody roots; common light gray Ca concretions; some black decaying organic matter; clear boundary

Very dark gray to very dark grayish brown (10YR 3/1 to $10 \mathrm{YR} 3 / 2$ ) clay; blocky with heavy clay skins on ped faces and soil partings; firm; few snail shell fragments; few krotovina filled with tan-colored clay; some black decaying organic material; few hard light gray Ca concretions 
Backhoe Trench Profiles

Depth (cm) Soil Zone Description

\begin{abstract}
BHT 3 On west side of Cell D
0-80 C $\quad$ Brown (10YR 5/3) clay; firm; massive; abundant decaying plant material; abundant modern debris and plastic; abrupt smooth boundary marked by two 5-cm thick layers of sand

80-138 Fill Clay containing STYROFOAM, rusting metal, and abundant plastic and glass; some charcoal and construction gravel; base abrupt and irregular and marked by a 5-cm layer of yellow cushion sand and large construction gravels

138-228 Disturbed Dark gray (10YR 4/1) clay; firm; massive; few snail shell fragments; entire to $2 \mathrm{Bb} \quad$ zone may have been disturbed; upper 20-30 $\mathrm{cm}$ heavily impacted and contains few large gravels, small medical bottles and broken glass, Ivory tinted whiteware, charcoal, abundant decaying organic matter, and is heavily mottled
\end{abstract}

\title{
BHT 4 Center of Cell D roughly $225 \mathrm{~m}$ south of north end of project \\ 0-35 C \\ 35-73/85 Fill \\ 73/85-185 2Ab to \\ 2ABbca \\ 185-275 2B1bca \\ 275-300 2B2bca \\ Brown (10YR 5/3) sandy clay; firm to friable; massive; sand content varies with depth; abundant fine woody roots; some modern debris; clear to gradual boundary \\ Yellowish brown (10YR 5/8) sand; friable; massive; abundant rounded gravel; very abundant glass, plastic, string; rusting metal; abrupt, irregular boundary. Appears to be historic surface dump material \\ Very dark grayish brown to dark brown (10YR 3/2 to 10YR 3/3) clay; very \\ firm; blocky; common fine woody roots in upper part; few snail shell fragments; common open rootlet holes; upper portion disturbed with some red Fe mottles; few light gray Ca concretions in lower part \\ Dark gray (10YR 4/1) clay; firm to slightly plastic; massive in upper part and coarse blocky with heavy clay skins in lower part; becomes increasingly wet with depth; some black decaying organic matter; some decaying organic matter with dark gray reduction haloes; few light gray Ca concretions; gradual to diffuse boundary \\ Very dark gray to dark gray (10YR 3/1 to 10 YR 4/1) clay; firm to very firm in upper part and plastic at base; blocky with heavy clay skins; common hard light gray Ca concretions; white Ca deposits along rootlet traces; color of zone varies with number of reduction spots and amount of black decaying organic matter
}

\section{BHT 5 Center of Cell $D$ at east edge of abandoned sludge pit \\ 0-55/60 Pit Seal Dark gray (10YR 4/1) clay; massive; firm; few pieces of decaying wood; common rootlets and woody roots; few rounded gravels; smooth, slightly wavy boundary}


Backhoe Trench Profiles

\begin{tabular}{|c|c|c|}
\hline Depth (cm) & Soil Zone & Description \\
\hline $\begin{array}{r}55 / 60- \\
140 / 150\end{array}$ & Pit Fill & $\begin{array}{l}\text { Dark brown (10YR 4/3) sandy clay; massive; firm; few fine woody roots; } \\
\text { large pieces of decaying wood; some glass and plastic; abundant open } \\
\text { rootlets and orange Fe mottles; appears to be pit fill with edge of pit at the } \\
\text { current tree line }\end{array}$ \\
\hline 140/150-200 & $\mathrm{C}$ & $\begin{array}{l}\text { Upper } 10 \mathrm{~cm} \text { black to very dark gray (10YR } 2 / 1 \text { to } 10 \mathrm{YR} 3 / 1) \text {, remainder of } \\
\text { zone very dark grayish brown (10YR 3/2) clay; very plastic and water } \\
\text { saturated; massive; abundant dark red Fe mottles in lower part; upper } 10 \mathrm{~cm} \\
\text { contains abundant white snail shells and has fibrous feel; water table at } \\
193 \mathrm{~cm} \text { below surface }\end{array}$ \\
\hline
\end{tabular}

\begin{abstract}
BHT 6 Center of Cell D south of abandoned sludge pit
0-15 C $\quad$ Yellowish brown (10YR 5/4) clayey sand; loose to friable; massive; common woody roots; abrupt, slightly irregular boundary

15-98 2Ab $\quad$ Very dark gray to dark gray (10YR 3/1 to 10YR 4/1) clay; very firm; blocky with heavy clay skins on peds and soil partings, soil structure increases and becomes coarser with depth; common white snail shell fragments; few fine woody roots; few krotovina filled with tan clay; gradual to diffuse boundary

98-174 2Bb Very dark gray to dark gray (10YR 3/1 to 10YR 4/1) clay; very firm; blocky to coarse blocky with heavy clay skins on ped faces; color slowly lightens with depth; becomes more plastic with increasing moisture with depth; common fine rootlets and worm burrows; gradual to diffuse boundary

174-305 2Cca Very dark grayish brown to dark grayish brown (10YR 3/2 to 10YR 4/2) clay; firm to slightly plastic; massive to weak blocky; some white calcareous deposits along rootlet traces, white deposits increase with depth; some snail shell fragments; clay skins on soil partings; some fine krotovina; tan and gray Ca concretions in lower part
\end{abstract}

\title{
BHT 7 Center of Cell D approximately $200 \mathrm{~m}$ north of south edge of survey area 0-82 C Dark grayish brown (10YR 4/2) slightly sandy clay; massive; firm; upper few centimeters more sandy; abundant fine woody roots; common woody roots; common decaying wood; some plastic and glass; gradual to diffuse boundary. Probably disturbed \\ 82-162 2C1 Dark grayish brown (10YR 4/2) clay; massive to fine blocky with clay skins on ped faces; firm; few decaying roots; few fine woody roots; few snail shell fragments; few pieces of decaying bark (look like bark chips); gradual to diffuse boundary \\ 162-300 2C2ca Dark gray (10YR 4/1) clay; firm to slightly plastic, growing more plastic with depth; massive; common decaying rootlets; common white calcareous deposits along rootlet traces; common fine krotovina filled with tan-colored clay; common snail shells; common light gray Ca concretions which increase in number with depth
}


Backhoe Trench Profiles

Depth $(\mathrm{cm})$ Soil Zone Description

\begin{tabular}{cll} 
BHT 8 & \multicolumn{2}{c}{ Center of Cell D approximately 100 m north of south edge of survey area } \\
$0-30$ & C & $\begin{array}{l}\text { Brown (10YR 5/3) slightly sandy clay; firm to slightly friable; massive; some } \\
\text { modern debris; common woody roots; clear boundary }\end{array}$ \\
$30-159$ & $\begin{array}{l}\text { 2ABb to } \\
\text { 2B1b }\end{array}$ & $\begin{array}{l}\text { Dark grayish brown (10YR 4/2) clay; firm; massive at top becoming fine } \\
\text { blocky with clay skins on ped faces with depth; abundant rootlets in upper } \\
\text { 50 cm; few snail shell fragments; some decaying organic matter with dark } \\
\text { gray reduction haloes; diffuse boundary }\end{array}$ \\
& $\begin{array}{l}\text { 2B2b to } \\
\text { 2Cca }\end{array}$ & $\begin{array}{l}\text { Dark gray to dark grayish brown (10YR 4/1 to 10YR 4/2) clay; massive to } \\
\text { coarse blocky with heavy clay skins on ped faces; firm to very firm; common } \\
\text { white calcareous deposits along rootlet traces; common fine krotovina filled } \\
\text { with material from overlying zone; few snail shell fragments; few fine woody } \\
\text { roots; amount of white calcareous deposits increase slightly with depth with } \\
\text { tan-gray, hard Ca concretions in lower } 40 \mathrm{~cm}\end{array}$
\end{tabular}
BHT 9 At west edge of Cell D west of BHT 8
0-32 C
Dark brown (10YR 4/3) slightly sandy clay; massive; firm; abundant rootlets; abrupt, wavy boundary
32-63/70 2C Cross bedded and cross laminated sand and clay; sand is light yellowish brown to very pale brown (10YR 6/4 to 10YR 7/4), friable to loose, and massive; clay is dark brown (10YR 4/3); few woody roots; few rootlets; several large vertical krotovina (crayfish?) penetrate into underlying zone; top of underlying zone reworked into base of this zone; boundary abrupt, smooth, and wavy
63/70-105 Fill Dark grayish brown (10YR 4/2) clay; massive; firm; few woody roots; common rounded gravels and concrete; clear boundary. Zone disturbed by construction
105-185 3BC Dark grayish brown (10YR 4/2) clay; massive; firm; some decaying organic matter; few snail shell fragments; diffuse boundary
185-220 3C Dark grayish brown to grayish brown (10YR 4/2 to 10YR 5/2) clay; firm; massive; common white calcareous deposits along rootlet traces

\footnotetext{
BHT 10 Near west edge of Cell D west of BHT 6

0-55 Fill Mixed orange cushion sand and gray clay; abundant glass, bricks, concrete fragments, and bottles; common woody roots; clear to abrupt boundary

55-84 C $\quad$ Dark gray (10YR 4/1) clay; firm; massive; common rounded gravels; few large decaying logs; clear boundary. Disturbed by construction

84-137 2Ab to Very dark gray to dark gray (10YR 3/1 to 10YR 4/1) clay; blocky with clay

2B1b skins on ped faces, some ped faces have gray silt coats; firm; few fine rootlets; few snail shell fragments; boundary is gradual to diffuse
} 


\title{
Backhoe Trench Profiles
}

\author{
Depth $(\mathrm{cm})$ Soil Zone Description
}

137-220 2B2b to Dark gray to dark grayish brown (10YR 4/1 to 10YR 4/2) clay; firm to 2C slightly plastic; massive to weak fine blocky with clay coats on ped faces; few rootlets; some snail shell fragments; some fine krotovina filled tancolored clay; lower portion of zone slightly darker probably due to gleying 


$$
\text { A-8 }
$$




\section{APPENDIX B}

\section{SELECTED PREVIOUSLY RECORDED}

GEOPROBE ${ }^{\circledR}$ EC PROFILES WITH INTERPRETED ALLUVIAL UNITS RELEVANT TO WETLAND CELL D 